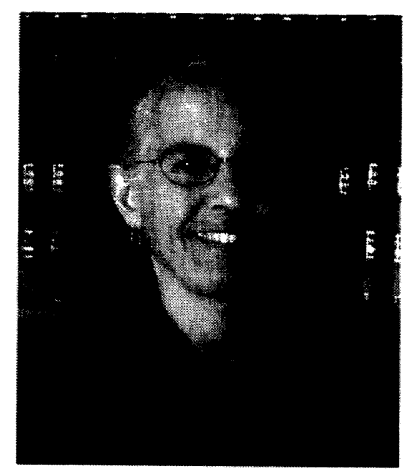

Leslie P. Francis

Leslie P. Francis is Alfred C. Emery Professor of Law; Professor and Chair, Department of Philosophy; and a member of the Division of Medical Ethics in the Department of Internal Medicine at the University of Utah. She received her Ph.D. in Philosophy from the University of Michigan in 1974 and her J.D. from the University of Utah in 1981. She was a law clerk to Judge Abner Mikva of the United States Court of Appeals for the District of Columbia Circuit in 1981-82.

Professor Francis specializes in Ethics, Bioethics, Philosophy of Law, Health Law, and Disability Law. She is the author of a number of articles on issues in philosophy of law, health care, and professional ethics. Her most recent books are LAND WARS: THE POLITICS OF PROPERTY AND COMMUNITY (with John G. Francis, Lynne Rienner Publishers 2003), and SEXUAL HARASSMENT AS AN ETHICAL ISSUE IN ACADEMIC LIFE (Roman and Littlefield 2001). She also has edited (with Anita Silvers) AMERICANS WITH DISABILITIES: IMPLICATIONS OF THE LAW FOR INDIVIDUALS AND INSTITUTIONS (Routledge 2000). She is currently a member of the American Law Institute (elected 1986), Chair of the Program Committee for the Pacific Division of the APA, and Immediate Past President of AMINTAPHIL. In the spring of 2000, she was awarded the University's Rosenblatt Prize for overall excellence in research, teaching, and academic service. 



\title{
LEGITIMATE EXPECTATIONS, UNREASONABLE BELIEFS, AND LEGALLY MANDATED COVERAGE OF EXPERIMENTAL THERAPY
}

\author{
Leslie Pickering Francis*
}

\section{INTRODUCTION}

Photographs of patients seeking contributions for expensive bone marrow transplants are an everyday image on supermarket checkout stands. Benefit concerts, newspaper stories, and community fundraisers pitch in to help patients who cannot otherwise afford expensive medical interventions. Patients with multiple myeloma lined up to testify before the Medicare Coverage Advisory Committee about the lifesaving possibilities of "their" bone marrow transplants. ${ }^{1}$ Many of the patients who are the subjects of these appeals have health insurance, but their insurance has denied coverage because the care has been judged to be experimental or not reasonably medically necessary. Behind these appeals for funding lies the judgment that these patients are not receiving care to which they are entitled-at least, care to which they are sufficiently entitled to deserve community support for their fundraising efforts.

Are these patients justified in their claims? Should health insurance routinely cover the costs of experimental therapy? Do patients have a moral claim that their legitimate expectations have been disappointed when the care is not covered? Patients and their advocates understandably urge coverage, especially when the therapy is expensive and lives are apparently on the line. In contrast, understandably, insurance plans would prefer to limit coverage for expensive interventions of marginal value. Ideally, all are interested in ensuring that patients receive proper care while also reducing the likelihood of ineffective or dangerous interventions. In the midst of this debate, a number of states have recently enacted coverage mandates for off-label drug uses and for patient participation in clinical trials (see Part IV). One policy goal of at least some of these statutes is to ensure that patients receive therapeutically beneficial care. Alabama, New Jersey, and Tennessee, for example, mandate coverage for patients receiving prescriptions for certain off-label drug uses; their stated legislative purpose is that the patients' "expectation that their

* Leslie Pickering Francis, Ph.D., University of Michigan, 1974; J.D., University of Utah, 1981; Alfred C. Emery Professor of Law and Professor and Chair, Department of Philosophy, University of Utah.

1. Drugs, Biologics, \& Therapeutics Advisory Panel, Medicare Coverage Advisory Comm., Minutes of the June 15, 1999 Meeting, available at http://www.cms.gov/mcac/8b1d5 .asp? origin $=$ globalsearch $\&$ page $=/ \mathrm{mcd} /$ viewmcac .asp id $=10$. 
health care costs will be paid by their insurance policies is not disappointed."2 This statutory policy apparently assumes that patients' legitimate expectations for therapeutic care extend to the covered off-label uses. An additional statutory justification for the coverage mandates is the desire to encourage the development of evidence-based medical knowledge about new therapies. Further justifications are drawn from distributive justice concerns-all patient populations should be included in the development of new medical knowledge, and promising new therapies should be available on an equitable basis.

This Article explores whether "legitimate expectations" for treatment are a persuasive moral reason to mandate insurance coverage of experimental therapy. It argues that legitimate expectations for coverage of therapeutic care extend only to limited cases of experimental interventions. Some of the statutory mandates exceed this justification in significant ways. Reasons based in justice and in evidence-based medical knowledge support some mandated coverage, but this logic does not rest primarily on the patient's own entitlement to care. Moreover, the encouragement of patients' expectations that experimental care will be funded may continue to induce problematic litigation by patients seeking the coverage. A principal example is coverage of highdose chemotherapy with stem cell support for patients with breast cancer, which is a politically and emotionally charged issue but is by no means unique.

\section{THE REASONABLENESS OF EXPECTATIONS AND THE LEGITIMACY OF BELIEFS}

This essay is part of a larger project exploring the moral import of expectations. The goal of the larger project is to explore when, if ever, and why the fact that people have formed expectations-beliefs about the future that they treat with an attitude of reliance-matters morally to how they ought to be treated. Respecting expectations is an aspect of treating people as choosers and planners of their lives; it is part of what we must do if we are to respect autonomy in practice. But not all expectations matter, and some that do matter bear only limited moral weight. One critical aspect of whether and with what weight expectations make a difference to how people ought to be treated is whether the expectations are based in reasonable beliefs. This aspect of expectations-the reasonableness of the beliefs on which they are based and their resulting moral significance-is the subject of this Article.

In enacting these statutes, the legislatures of Alabama, New Jersey, and Tennessee stated explicitly that their goal was to protect the legitimate expectations of patients. These expectations, as the legislatures understood them, rested on two related sets of beliefs. First, patients - and the legislators who acted to support them-believed the off-label therapies at issue were 
likely to be of significant medical benefit. ${ }^{3}$ Second, patients believed their health insurance covered reasonable health care costs for medically beneficial care. ${ }^{4}$ At least part of the support for the latter belief lies in the typical language of health insurance contracts specifying that the scope of coverage encompasses reasonable and necessary care. Specifically limited health insurance, such as dental insurance, quite clearly would not create the legitimate expectation of more general coverage. The difficult question is whether any off-label therapy falls within the general scope language extending coverage to care that is reasonable and necessary. The first set of beliefs-beliefs about the likely benefit to be obtained from off-label therapy-is central to answering this question, because the argument that the care is reasonable and necessary rests on the likely benefit to be obtained from it. Thus patients' beliefs-that care would be beneficial and thus covered-were crucial to the purpose of the statutes. But are these beliefs reasonable? If not, what conclusions should we draw about the statutory mandates? Do the mandates merely bootstrap unreasonable original expectations into a new set of expectations based in the statutes themselves? Or, do the statutes reinforce expectations that were originally legitimate?

The reasonableness of beliefs is a complex matter. Objective reasonableness is linked to whether the beliefs are true or false. Respect for persons as choosers and planners of their lives, however, must be based on the world as they see it, not as it objectively might appear from a detached perspective. ${ }^{5}$ Beliefs that are founded upon the best available evidence may eventually be discovered to be false. In addition, people may hold beliefs that happen to be true but that are accepted for remarkably irrational reasons.

Respecting autonomy requires respecting choices based upon beliefs that seemed well founded when the choice was made, even if the beliefs might later be rejected. Conversely, respecting autonomy does not require honoring irrationally accepted expectations or expectations based on beliefs that are known to be false or that reasonably should be regarded as suspect. Autonomy is reasoned choice, not unfounded choice. To the same effect is the consequentialist concern that honoring expectations based upon beliefs reasonable people should know are false may create counter-productive incentives for unreasonable reliance. Subjective reasonableness is thus more relevant to expectations than objective reasonableness. But what does subjective reasonableness demand in areas of life where people are likely to be unreasonable-

3. In the language of these legislatures, "Denial of payment for off-label use can interrupt or effectively deny access to necessary and appropriate treatment for a person being treated for a life-threatening illness." ALA. CODE § 27-1-10.1(3) (2003); N.J. STAT. ANN. § 26:1A-36.9(d) (West 2003); TENN. CODE ANN. § 56-7-2352(4) (2003).

4. The statute might simply have mandated the coverage. To say that the coverage is "legitimately expected" suggests that patients believe it will be forthcoming, and that these beliefs ought to be honored. Using the language of expectations suggests that what people believe plays a role in justifying the coverage.

5. See THOMAS NAGEL, THE VIEW FROM NOWHERE (1986). 
areas that are momentous, but difficult to understand and emotionally challenging?

Health care is clearly such an area. Even leaving emotions aside, health care decisions often require significant scientific and technical expertise. Medical care, especially complex care for diseases that are serious and difficult to treat, is a context in which expert advice appropriately looms large. Patients' beliefs about the likely efficacy of care are more reasonable when they are based on the recommendations of recognized experts-for example, physicians in centers designated as comprehensive cancer centers by the National Cancer Institute ("NCP"). ${ }^{6}$

In addition, health care is not an area where emotions can be left aside; patients with life-limiting illnesses are understandably frightened and vulnerable. Moreover, such patients may be in a state of mind in which their powers of independent understanding are not as fully operative as they might be in other circumstances, such as understanding architectural advice in homebuilding. In facing serious illness, patients struggle to understand difficult scientific concepts and understandably rely on expert advice. A patient's belief that therapy is likely to be safe and effective, when reached after consultation with a reasonable expert, is thus subjectively reasonable. This is not to say that all expert advice is, in turn, reasonable. How, then, does a judgment about the reasonableness of experts' beliefs affect a judgment about the reasonableness of a patient's beliefs?

One important factor regarding a patient's belief is the degree to which the experts' beliefs have scientific support. Available evidence may range from promising results in a few treated patients-results that may be suggestive but may also be limited to certain patients-to a well-designed, randomized clinical trial. ${ }^{7}$ Moreover, experts may be swayed by enthusiasm generated by genuinely promising results in the most recent patients treated. Experts may also be affected by financial interests in the research they are conducting. ${ }^{8}$ At a minimum, experts should be aware of the level of evidentiary support for their claims and any potential for conflict of interest. They should also attempt to make these factors transparent to patients. ${ }^{9}$

6. See Nat'l Cancer Inst., The National Cancer Institute Cancer Centers Program, at http://cis.nci.nih.gov/fact/1_2.htm (last visited July 25, 2003) (describing this designation, including the requirement for rigorous peer review).

7. See Executive Comm. Working Group, Medicare Coverage Advisory Comm., Recommendations for Evaluating Effectiveness (Feb. 23, 2001), available at http://www.cms .hhs.gov/mcac/8b1-i9.asp (discussing different levels of evidentiary support) [hereinafter Medicare Coverage Advisory Comm.].

8. See Karine Morin et al., Managing Conflicts of Interest in the Conduct of Clinical Trials, 287 JAMA 78 (2002) (discussing how conflicts of interest may affect the conduct of clinical trials).

9. The transparency model of informed consent has been explored and defended by Howard Brody. The basic idea is that the physician's reasoning should be made clear (transparent) to the patient as part of the process of informed consent. See Howard Brody, Transparency: Informed Consent in Primary Care, 19 HASTINGS CENTER REP. 5 (1989). 
Experts, however, may fail to explain these differences carefully. Physicians have difficulty admitting and explaining uncertainty to patients. ${ }^{10}$ Recent studies of patients' understanding of medical research indicate that roughly half do not even understand that they are participating in research. ${ }^{11}$ When a physician describes therapy in terms of chances of cure or partial remission, the patient may easily misunderstand. For example, informed consent forms for participation in clinical trials often begin with a statement that the trial is for the purpose of research but then continue to include treatment language: "you will begin treatment on day one" and "treatment will continue until your disease progresses," rather than "your entry into the research will begin on day one," and "your participation in the study will continue until your disease progresses." Consent forms may include a schedule of evaluation extending over many years or "for life," when in fact the expected endpoint of the research is only a few months of event-free survival.

Another factor confounding judgment of subjective reasonableness is how people frame information about risk. Tversky, Kahneman, and other students of decision theory have demonstrated that the description of a decision problem affects choice. Faced with the same gambles described differently, people do not consistently elect the option with the maximum expected utility. ${ }^{12}$ That is, they do not behave rationally, if rationality is understood in terms of utility maximization. Instead, they are risk averse when offered the option of an assured gain versus a lottery with a chance of no gain but a higher expected payoff value. At the same time, people are risk acceptant when offered the parallel option of an assured loss versus a lottery with a chance of no loss but a higher expected negative payoff. ${ }^{13}$ Psychologically, people want to gain something but lose nothing; whether a decision is framed as a potential loss or a potential gain makes much of the difference in how they choose. ${ }^{14}$ Tversky and Kahneman further argue that these and other descriptive findings about how people make choices should be of interest to the normative theory of rational choice. ${ }^{15}$ Tversky and others have demonstrated this phenomenon in health care in the context of the choice between surgery and radiation for lung cancer. ${ }^{16}$ Arguably, then, experts

10. See JAY KATZ, THE SILENT WORLD OF DOCTOR AND PATIENT (1984).

11. Nancy E. Kass et al., Trust: The Fragile Foundation of Contemporary Biomedical Research, in INTERVENTION AND REFLECTION 494-99 (Ronald Munson ed., Wadsworth 6th ed. 2000).

12. Daniel Kahneman \& Amos Tversky, Choices, Values, and Frames, in CHOICES, VALUES, AND FRAMES 1-16 (Daniel Kahneman \& Amos Tversky eds., 2000).

13. Id.

14. Id.

15. Id. at 209-23.

16. B.J. McNeil, S.C. Pauker, H.C. Sox, Jr., \& A. Tversky, On the Elicitation of Preferences for Alternative Therapies, 306 NEW ENG. J. MED. 1259 (1982). Surgery involves a chance of death during the actual therapy, unlike the alternative of radiation. Id. However, the overall survival data are better for surgery. Id. Patients were less likely to opt for surgery 
advising patients should be aware of these framing effects and should be discouraged from using them as a strategy to influence patients' choices. ${ }^{17}$ In sum, reliance on experts, by itself, does not undermine the reasonableness of patients' beliefs. However, for the reliance to be reasonable, experts should strive to be clear about evidentiary support and about their own possible conflicts of interest, and also should strive to not play upon known factors affecting patient misperceptions.

Although reinforcement likely starts with reliance on expert advice, as described above, general social reinforcement arguably also affects beliefs about medical care. For example, newspaper reports of promising new therapies, rumors that a "cure" is just around the corner, or anecdotal reports of success from neighbors or friends may all feed unrealistic expectations about what is likely or possible from medical research. It is difficult to disentangle the respective influence of such reinforcement, much less determine whether reliance on it is reasonable.

The simplest claim about reasonableness would be that the more authoritative the source of reinforcement, the more reasonable the belief. Thus, scientific reporting in newspapers such as the New York Times, information on reputable web sites such as that of the NCI, official reports from government agencies, and reinforcement found in statutes, administrative regulations, and judicial decisions would be considered more authoritative than, for example, a neighbor's account of a supposedly promising new therapy. For this reason, the role of legal mandates in creating expectations about entitlement to medical care warrants particularly careful scrutiny. Part five (V) below, however, argues that legislatures and courts have not been as careful as they should be about the expectations they have created.

All of these factors affecting subjective reasonableness-the vulnerability of patients, the importance of framing effects, the role of experts, and social reinforcement-converge in the situation of a patient with life-limiting cancer. Social policy and law pose additional complications in the case of cancer treatment. Patient advocacy groups and feminist groups have pressed the sympathetic situations of patients with breast cancer through language that assumes therapeutic efficacy for interventions such as high-dose chemotherapy with stem cell support. In response, a number of states have adopted coverage mandates for patients in clinical trials of new modalities of cancer

if the choice of therapy was posed in terms of risks of mortality rather than in terms of chances of survival. Id.

17. Other characteristic features of decision-making are also identified by work in the Tversky and Kahneman tradition. For example, the understanding of probability is not linear; people are far more influenced by the differences between 0 and $1 \%$ and between 99 and $100 \%$, than they are by other differences of $1 \%$ on the probability scale. This feature may be especially important when people additionally confuse a certainty ("cure") with a probability ("chance of remission") in medical decisions. See, e.g., Daniel Kahneman \& Amos Tversky, Prospect Theory: An Analysis of Decision Under Risk, in CHOICES, VALUES, AND FRAMES, supra note 12 , at 17-43. 
treatments (see Part IV). But these coverage mandates may outstrip the justifications for them based solely on therapeutic efficacy (see Part II). Even more in the public eye, breast cancer patients (or their estates) have won highprofile lawsuits challenging their insurers for denying coverage for high-dose chemotherapy with stem cell support (see Part V). These cases foster the assumption that the care would be life-saving, and the concomitant conclusion that such care should be provided as a matter of entitlement.

\section{HIGH-DOSE CHEMOTHERAPY WITH STEM CELl SUPPORT FOR BREAST CANCER: THE CLINICAL STORY}

\section{A. The Therapeutic Strategy}

High-dose chemotherapy has been explored as a therapeutic option for a number of different types of cancer. This type of therapy has the advantage of potentially eradicating cancers that cannot be treated successfully with lower doses of chemotherapy.$^{18}$ The disadvantages include cost-which may, depending on the patient's condition and complications of therapy, approximate $\$ 250,000^{19}$-and toxicity. High-dose chemotherapy, administered systemically, will kill all cells in the body that divide more rapidly than others, including bone marrow cells (the clinical term for destruction of bone marrow cells is "myoablative"). Without functioning bone marrow, patients are unable to produce new blood cells and will die from infection, hemorrhage, or anemia. Accordingly, patients receiving high-dose chemotherapy must be supported by a re-infusion of cells that can recreate functioning bone marrow. During the period before bone marrow function returns, such patients are at risk of infection and other complications; the risk of death in the period of administration of high-dose chemotherapy and immediately thereafter is as high as ten percent, depending on the patient population. ${ }^{20}$

If the patient donates the re-infused cells, the transplant is autologous. If a matched donor provides the cells, the transplant is allogeneic. The re-infused cells may be harvested bone marrow cells or circulating stem cells. Autologous transplants avoid graft-versus-host disease and have a lower rate of death associated with the immediate transplant procedure; however, autologous transplants may be less successful long term because of the

18. For a good description of high dose chemotherapy with stem cell support, see Nat'1 Cancer Inst., Bone Marrow Transplation and Peripheral Blood Stem Cell Transplantation: Questions and Answers, at http://cis.nci.nih.gov/fact/7_41.htm (last visited Feb. 5, 2004).

19. For a good discussion of the direct and indirect costs of bone marrow transplantation, see NAT' L BONE MARROW TRANSPLANT LINK, A RESOURCE GUIDE FOR BONE MARROW/STEM CELL TRANSPLANT (2001), at http://www.nbmtlink.org/rg.asp\#cost (last visited Mar. 29, 2004).

20. INT'LMYELOMAFOUND., UNDERSTANDING AUTOLOGOUS BONE MARROW ANDSTEM CEll TRANSPlantation: HeRE's What You ShOULD KNow 23, at http://myeloma.org/ images/content_pdf/BMT.pdf (last visited Mar. 29, 2004). 
possibility the disease will not be fully eradicated. ${ }^{21}$ Very recently, some transplant programs have been exploring lower-dose chemotherapeutic regimes coupled with allogeneic transplants. These programs are called minitransplants. Higher-risk patients may be better able to tolerate the chemotherapeutic regimens involved. Additionally, there is some hope that the mixed chimerism of the patient's own bone marrow, not fully ablated by the chemotherapy, together with the donor marrow, will create an immune reaction of independent therapeutic efficacy. ${ }^{22}$

In the 1980s, a number of transplant programs began exploring highdose chemotherapy with transplant support for the treatment of metastatic breast cancer. Early reports suggested the therapy might be effective, although these reports came from smaller (Phase II) trials that did not randomize patients and that did not report survival data over the long term. ${ }^{23}$ The procedure came to be seen as life-saving, even miraculous. One court's opinion in a challenge by a patient to her insurer's denial of coverage was typical:

In light of the medical testimony that HDC-ABMT [highdose chemotherapy-autologous bone marrow transplant] is an effective form of therapy for breast cancer and that breast cancer patients who earnestly seek the treatment experience better prognoses than those who choose conventional treatments, we find that the trial court did not err in finding that HDC-ABMT is not experimental or research in nature $\ldots .^{24}$

Other courts credited the therapy with lengthening life or improving the quality of life, despite very short durations of survival for patients. ${ }^{25}$ This enthusiasm, however, has been dashed by subsequent research. Recent studies indicate no long-term or relapse-free survival benefit associated with highdose chemotherapy and stem cell support for breast cancer patients generally, although research is ongoing. ${ }^{26}$ The NCI web site designed for health care providers opines that "[i]n the absence of data suggesting a benefit from high-

21. See generally id. (discussing autologous bone marrow transplants for multiple myeloma).

22. See, e.g., Duke Univ. Health Sys., About the Procedure: Bone Marrow Transplant \& Stem Cell Transplant Program, at http://bmt.mc.duke.edu/procedure/types-minitransplant.asp (last visited Mar. 29, 2004).

23. See, e.g., W.P. Peters et al., High-Dose Combination Alkylating Agents with Bone Marrow Support as Initial Treatment for Metastatic Breast Cancer, 6 J. CLINICAL ONCOLOGY 1368 (1988) (study at Duke University).

24. Taylor v. Blue Cross/Blue Shield of Mich., 517 N.W.2d 864, 869-70 (Mich. Ct. App. 1994).

25. See, e.g., Scalamandre v. Oxford Health Plans, Inc., 823 F. Supp. 1050 (E.D.N.Y 1993) (The patient had the procedure performed in September and October and then died the following January).

26. For a good overview, see Astrid Mayer \& Helena Earl, Whither High-Dose Chemotherapy in Breast Cancer? 3 BREAST CANCER RESEARCH 8 (2001). 
dose chemotherapy with stem cell support, this remains an area of clinical evaluation." 27 Toward this end, several clinical trials are ongoing. ${ }^{28}$ The trials vary by chemotherapeutic regimen; some trials are of higher dose regimens and others of mini-transplants. These clinical trials have stringent criteria for entry, including patient age, disease stage, and prior treatment history; they are designed more for research than treatment purposes.

Nationwide, sophisticated patients seeking information about cancer treatment have increasingly turned to the Internet. Patients who explore web sites of major cancer centers, however, will encounter significantly different views of the current status of myoablative therapy with stem cell support for breast cancer. An August 2003 survey of the web sites of the forty-two centers designated as Comprehensive Cancer Centers by the National Institutes of Health ("NIH") reveals that twenty-four of these web sites feature readily accessible, extensive, and clear descriptions of the difference between a clinical trial and treatment. ${ }^{29}$ On some web sites, however, the description of the difference is difficult to find ${ }^{30}$ or requires following a link to another site. ${ }^{31}$ Some of these web sites even list high-dose chemotherapy with stem cell support as a possible treatment option for breast cancer. The Lombardi Cancer Center at Georgetown University features a "success story" of a patient who survived breast cancer through a bone marrow transplant. ${ }^{32}$ The City of Hope in Los Angeles boasts 5200 bone marrow transplants performed, the third largest number in the United States. ${ }^{33}$ Its site includes testimonials of two patients with advanced breast cancer. The web site description does

27. Nat'1 Cancer Inst., Stage $111 B, 111 C, I V$, Recurrent, and Metastatic Breast Cancers: Cytotoxic Chemotherapy, available at http://www.cancer.gov/cancerinfo/pdq/treatment/breast/ healthprofessional/\#Section_278 (last visited Nov. 24, 2003) (citing D.A. Berry et al., HighDose Versus Standard Chemotherapy in Metastatic Breast Cancer: Comparison of Cancer and Leukemia Group B Trials with Data from the Autologous Blood and Marrow Transplant Registry, 20 J. CLINICAL ONCOLOGY 743 (2002)).

28. Nat'l Cancer Inst., Clinical Trials, available at www.cancer.gov/clinicaltrials/ (last visited Mar. 16, 2004). The site is updated frequently to indicate the number of open trials of high-dose chemotherapy in which breast cancer patients are included. The listed trials vary by patient population, type of chemotherapy or radiation therapy, and therapeutic intensity.

29. Data on file with the author and the Indiana Health Law Review.

30. See, e.g., The Abramson Cancer Ctr. of Univ. of Pa., at www.oncolink.com (last visited Nov. 24, 2003).

31. See, e.g., Univ. of N.C. Lineberger Comprehensive Cancer Ctr., at http://cancer.med .unc.edu/patient/default.asp (last visited Jan. 1, 2004).

32. Lombardi Cancer Ctr., Success Stories: Surviving Cancer, at http://lombardi .george town.edu/success/surviving.htm (last visited Jan. 1, 2004).

33. City of Hope, at http://www.cityofhope.org (last visited Nov. 24, 2003) (providing many success stories of treating breast cancer patients with bone marrow transplantation). Other comprehensive centers with web sites which suggest that bone marrow transplantation might be available as a treatment for breast cancer include the Norris Center at University of Southern California, at http://ccnt.hsc.usc.edu/services/breast_cancer/treatment.htm(last visited Nov. 24, 2003), and the Chao Center at University of California-Irvine, at http://www.ucihealth.com/ cancer/index.htm (last visited Nov. 24, 2003). 
note that seventy-five percent of the cases treated at the City of Hope involve leukemia or lymphoma (cancers in which the bone marrow itself is a cancer site), but lists breast cancer as an "other malignancy" treated. ${ }^{34}$ The Roswell Park Cancer Institute at State University of New York-Buffalo lists autologous bone marrow transplantation as a treatment option for "select" patients. ${ }^{35}$ The M.D. Anderson Cancer Center web site contains a careful description of clinical trials, their risks, and the possibility that insurance will not pay for them. ${ }^{36}$ A separate location on the web site lists all of the clinical trials ongoing at the center, without the implication that clinical trial participation is indicated therapy. It also, however, lists myoablative therapy with stem cell support as a treatment option for advanced breast cancer. The Fred Hutchinson Cancer Research Center in Seattle contains a glowing description of a reunion of bone marrow transplant patients, which includes this text:

Malignant diseases such as breast cancer and others are now being treated in this way, since the same general principles of destroying malignant cells with mega doses of drugs and radiation are used. Responses in breast cancer vary, but more time is necessary to evaluate the long-term results. Some autoimmune diseases are also now the subjects of treatment with stem-cell transplants. ${ }^{37}$

The Mayo Clinic, by contrast, does not include breast cancer as a solid tumor treated by bone marrow transplantation. ${ }^{38}$

A fair inference from this survey is that patients accessing the web sites of these designated comprehensive cancer centers may be at best confused about whether myoablative chemotherapy with stem cell support is currently regarded as standard, effective treatment for advanced breast cancer. Understandably, patients wanting the best medical care may conclude that because some centers offer this therapy as effective treatment, it is an option they should pursue and an option others should support as life-saving treatment for them.

34. Id.

35. Roswell Park Cancer Inst., Breast Center, at http://www.roswellpark.org/Document .asp?lid=723 (last visited Nov. 24, 2003).

36. The Univ. of Tex. M.D. Anderson Cancer Ctr., at http://www.mdanderson.org/ (last visited Nov. 24, 2003). A number of other cancer centers also have designed their web sites to list clinical trials separately.

37. E.D. Thomas \& D. Thomas, Fred Hutchinson Cancer Research Ctr., The Promising Future of Transplantation: Expanded Application of Hematopoietic Transplantation, at http://www.fhcrc.org/visitor/patient_experience/reunion.html (last visited Nov. 24, 2003).

38. Mayo Clinic, at http://www.mayoclinic.org/bmarrowtransplant-rst/ (last visited July 25, 2003). 


\section{B. Insurance Coverage for Myoablative Chemotherapy for Breast Cancer}

In the private market, health insurance coverage is established by contract. Insurance contracts typically provide coverage for medically indicated therapy, with enumerated exclusions and patient payment responsibilities. Contract language will likely exclude therapy that is "experimental" or "investigational" in the judgment of the insurer. Patients faced with coverage denials may challenge these judgments in court. Because more than eightyfive million patients are insured by its plans, Blue Cross and Blue Shield ("BC/BS") Association has been a leader in assessing the evidence supporting medical practices. ${ }^{39}$ The BC/BS Technology Evaluation Center ("TEC"), established in 1985 and working in collaboration with Kaiser Permanente since 1993, provides evidence-based evaluations. ${ }^{40}$ TEC does not list an evaluation of myoablative therapy with stem cell support for breast cancer, although it does for other cancers, such as multiple myeloma. In the case law, courts have expressed suspicion about technology assessment organizations and instead have relied on the testimony of treating oncologists. ${ }^{41}$

Medicare beneficiaries include both those qualifying for Social Security because they have worked the requisite forty quarter-years and those qualifying because they are disabled. Like BC/BS, Medicare often plays a major role in coverage determinations because it covers over forty million patients and invests a high level of technical scrutiny in coverage decisions. ${ }^{42}$ Under the Medicare statute, one criterion for coverage determinations is whether the intervention is "reasonable and necessary." ${ }^{43}$ As of this writing, cost is not listed as a factor in Medicare regulations governing judgments of reasonableness and necessity, ${ }^{44}$ although discussion of this issue may resume with the public policy spotlight on the costs of the Medicare program. Coverage decisions are based on whether data supports the efficacy of therapy in the population over the age of sixty-five or in other patients eligible for Medicare. ${ }^{45}$ A difficulty facing some coverage decisions is that there is little data about the safety or efficacy of some therapies in patients over the age of sixty-five. Myoablative chemotherapy is an example because of its toxicity. Some of the clinical trials now underway involving myoablative therapy for

39. Blue Cross Blue Shield Ass'n, at http://www.bcbs.com/tec/index.html (last visited July 25,2003 ).

40. Id.

41. See, e.g., Adams v. Blue Cross/Blue Shield of Md., 757 F. Supp. 661 (D. Md. 1991); Pirozzi v. Blue Cross-Blue Shield of Va., 741 F. Supp. 586 (E.D. Va. 1990).

42. Ctrs. for Medicare \& Medicaid Servs., at http://www.cms.gov/medicare/ (last visited Mar. 9, 2004) [hereinafter CMS web site].

43. 42 U.S.C. $\S 1395 y(a)(1)(A)$ (2003).

44. For the regulatory definition of the scope of Medicare covered services, see 42 C.F.R. $\S 402.3$ (2003).

45. Medicare Coverage Advisory Comm., supra note 7. 
breast cancer specify an upper age limit of sixty and thus will provide data that is at best indirectly relevant to the majority of the Medicare population. ${ }^{46}$

Medicare coverage decisions may be made nationally or by local carriers if there is not a national coverage determination. ${ }^{47}$ There is a national coverage determination that autologous stem cell transplantation is not covered for solid tumors, including breast cancer. The coverage decision was that there is insufficient evidence to show that high dose chemotherapy plus stem cell support is reasonable and necessary in the Medicare population. ${ }^{48}$ No national coverage determination has been issued for allogeneic transplants, but these transplants are not listed as covered services in the Medicare population for patients with solid tumors. ${ }^{49}$ Nor has there been a national coverage determination for mini-transplants. ${ }^{50}$

\section{INSURANCE COVERAGE FOR PATIENTS PARTICIPATING IN ClinicAL TRIALS}

Clinical trials are designed to evaluate whether new medical interventions are superior to standard patient management, including both treatment and diagnosis. The current canonical view is that clinical trials are not ethical without "equipoise:" there must be no good reason to believe that the innovation to be tested is either better or worse than standard management of the patient. $^{51}$ Without equipoise, the trial would be unethical because the patients

46. Examples are the trial of Allogeneic Peripheral Stem Cell Transplantation After Antithymocyte Globulin, High-Dose Melphalan, and Fludarabine in Treating Women with Metastatic Adenocarcinoma of the Breast, at $\mathrm{http}: / / \mathrm{clinicaltrials.gov/ct/show/NCT00074269?order}$ $=4$ (last visited Mar. 8, 2004), and the trial of Chemotherapy and Stem Cell Transplantation in Treating Patients with Stage IIIB Breast Cancer, at http://clinicaltrials.gov/ct/show/NCT0000 3042? order=7 (last visited Mar. 8, 2004).

47. Information about how Medicare coverage determinations are made is available on the CMS web site, at http://www.cms.gov/coverage/8a.asp (last visited Mar. 8. 2004) (especially the June 4, 2002 Report to Congress available on the web site).

48. The full list of national coverage determinations can be found on the CMS web site, at http://www.cms.gov/mcd/index_list.asp?list_type=ncd (last visited Mar. 8, 2004).

49. This information is from the CMS web site, at http://www.cms.hhs.gov/ncd/search display.asp?NCD_ID=45\&NCD_vrsn_num=4 (last visited July 25,2003 ). A number of local carriers have made parallel determinations that stem cell transplants are not covered for solid tumors in patients in the Medicare population. Id. These include the Wisconsin Physicians Service Insurance Corporation (for Wisconsin, Illinois, Michigan, and Minnesota), Palmetto Government Benefits (Ohio and West Virginia), Blue Cross and Blue Shield of Nebraska (Nebraska; also clarifies that "minitransplants" are not covered for solid tumors), Group Health, N.Y. (New York, Queens), HGS Administrators (Pennsylvania), First Coast Service Options (Florida), and Blue Cross and Blue Shield of Arkansas (Arkansas, New Mexico, Oklahoma, northeastern and southern Missouri, and Louisiana). Id.

50. CMS web site, at http://www.cms.gov/mcd/viewncd.asp?ncd_id=35-30.1\&ncd_ version $=5 \&$ show $=$ all (last visited Mar. 8, 2004).

51. Benjamin Freedman, Equipoise and the Ethics of Clinical Research, 317 NEw ENG. J. MED. 141 (1987). 
in one arm of the trial would be getting care already reasonably believed to be less good than care in one of the other arms of the trial. "Equipoise," however, may be at best an unattainable ideal and at worst the basis of misconceptions. Although it is not ethical to design a clinical trial that withholds management of known value, many clinical trials approved today appear to comport uneasily with the idea of equipoise. Fairly strong suspicions may be present among researchers that one arm of the trial is preferable to others, but unless the trial is stopped because of an adverse event or a significant result, it will continue. Many trials include a placebo arm, albeit infrequently in cancer trials. Even when there is a generally accepted standard therapy, placebo arms may be included if the risks to the patient are minimized and there is reason to believe there may be a large placebo effect or that the standard therapy carries disadvantages of its own. Many trials also include a washout period in which a patient discontinues existing medications, again if the risks to patients are minimized. These concerns about equipoise have led at least two authors to argue that the ethics of research and the ethics of therapy should be detached, lest research be confused with the most effective, patient-centered therapy. ${ }^{52}$

Randomized clinical trials are considered to give the best information about the efficacy of a given medical intervention. ${ }^{53}$ In such clinical trials, patients are selected according to entry criteria designed to elicit reliable and valid scientific information about the intervention being studied. ${ }^{54}$ Too much variance in patient characteristics, for example, might obscure whether differences in patients or in clinical management explain differences in outcomes. In the best clinical trials, patients are randomized among study arms to ensure that the variation being studied, and not variations among patients, is the relevant independent variable. ${ }^{55}$

Clinical trials of new therapeutic regimens are classified in "phases." 56 The primary goal of a Phase I trial is evaluation of safety, safe dosage ranges, and side effects. Therapeutic efficacy is only a secondary consideration. Phase I trials of cancer chemotherapy regimens generally enroll a small number of patients, from twenty to eighty. Patients are evaluated first at lower, possibly sub-therapeutic, dosages of the proposed regime. If patients at the lower dosage do not experience significant toxicities, patients are enrolled at higher dosage levels. Dose escalation ceases when two patients experience significant toxicities. Patients enrolled in Phase I trials generally

52. Franklin G. Miller \& Howard Brody, A Critique of Clinical Equipoise: Therapeutic Misconception in the Ethics of Clinical Trials, 33 HASTINGS CENTER REP. 19 (2003), available at 2003 WL 17821782.

53. Id.

54. Id.

55. Medicare Coverage Advisory Comm., supra note 7.

56. See generally Nat'1 Inst. Health, CancerTrials.gov, at www.clinicaltrials.gov (last visited Jan. 1, 2004) (providing a general overview of clinical trials and discussing phases). 
have exhausted other available therapies; therefore, it is considered ethical to offer them the possibility of benefit even if the trial's main goal is to establish tolerated dosage levels. Phase II trials randomize patients between the investigational regimen and a standard therapeutic regimen. Enrolling larger numbers of patients, from 100 to 300 , the trials are designed to see whether there are statistically significant differences between treatment arms and whether levels of toxicity are acceptable. Phase II trials focus on determining shortterm efficacy and safety of therapy. These trials have stopping rules under which they will be ended if reported toxicities are unacceptable or significant differences in efficacy become apparent. Phase III trials enroll a larger number of patients, typically from 1000 to 3000 , and are undertaken only if Phase II trials suggest further study is warranted. Phase III cancer trials typically require interim data analyses. They are stopped if there is clear evidence that one treatment arm is significantly preferable to others and, therefore, there is no longer clinical equipoise between the arms of the trial.

Phase IV trials undertake continued collection of data after a new drug is given marketing approval based on data from earlier trials. The goal of Phase IV is to collect data on an ongoing basis as an approved therapy becomes employed in the general population of patients in need of treatment. Distribution of a therapy into the general population of patients, outside the research context, may reveal quite different aspects of the therapy's risks and benefits.

Thus, the balance between scientific and therapeutic goals shifts with the phase of a clinical trial. For Phase I trials, therapeutic goals are clearly secondary, although the investigational regimen would not be under study without some reason to believe it holds therapeutic promise. For Phase IV trials, therapeutic goals are undoubtedly primary, with the secondary aim being the ongoing monitoring of safety and efficacy. However, it is not at all clear that patients understand the differences between these types of clinical trials, much less the difference between research and therapy itself.

The potential for confusion between therapy and research is so significant that the confusion has been given a label among writers in bioethics: the "therapeutic misconception." 57 If patients believe they are receiving what their physician regards as the "best treatment" for them, yet they are participating in a clinical trial in which they are randomized among treatment arms believed to be in equipoise, they fall under the therapeutic misconception. ${ }^{58}$ The confusion between research and therapy is of course most significant in Phase I trials, where the dosage level the patient receives may be set to evaluate something other than therapeutic efficacy. Patients assigned to the initial dosage levels, for example, may receive less efficacious therapy, but

57. Miller \& Brody, supra note 52.

58. Id. 
may also avoid more significant toxicities. ${ }^{59}$ The misconception is also present in Phase III trials, where patients may be randomized among treatment arms. In theory, Phase III trials are designed to be in equipoise; it would be unethical to expose a patient to the possibility of assignment to a treatment arm known to be less efficacious than other treatments. On the other hand, Phase III trials are undertaken against the background of suspicion that one arm will prove to be superior to the other(s). This background may be either inconclusive evidence that a new regimen is superior (e.g., evidence from a smaller Phase II trial), evidence that there are efficacy or toxicity problems with standard therapy, or other advantages to the therapy under investigation. Phase III trials are conducted in delicate balance between the need for data that are sufficiently significant to demonstrate the superiority of one treatment arm and the maintenance of sufficient clinical equipoise to permit continuation of the study.

The therapeutic misconception is fostered by the fact that patients with cancer face life-limiting illness. Patients are in situations of significant personal, physical, and frequently even financial vulnerability. By the time patients contemplate entering a clinical trial, they may have already attempted and, in the language of medicine, "failed" other available treatment options. Entry into a clinical trial may be an option of last resort. ${ }^{60}$ One important study suggests that patients entering clinical trials do not adequately understand that they are engaged in research or what being engaged in research actually means. ${ }^{61}$ Although ninety percent of patients in the study expressed overall satisfaction with the informed consent process, the majority (74\%) did not understand that they were receiving non-standard treatment. ${ }^{62}$ Many also did not understand the potential for additional risk presented by participation $(63 \%)$, did not understand that the treatment was unproven $(70 \%)$, did not understand the uncertainty of benefits to self (29\%), and did not realize that trials are done mainly to benefit future patients $(25 \%) .^{63}$ In this study, increased knowledge was associated with college education, English as the only spoken language at home, the use of the United States NCI consent form template, signing the consent form later than at initial discussion, presence of a nurse, and careful reading of the consent form. ${ }^{64}$ Other researchers have

59. Id.

60. See Benjamin Freedman, A Response to a Purported Ethical Difficulty with Randomized Clinical Trials Involving Cancer Patients, 3 J. CuINICAL ETHICs 231 (1992) (discussing issues regarding patients with cancer in clinical trials); Maria Merritt, Moral Conflict in Clinical Trials, Address Before the Pacific Division Meeting for the American Philosophical Association, Seattle, Wash. (Mar. 2002) (on file with the author) (discussing tensions between clinical duties and scientific duties in Phase I trials).

61. Steven Joffe et al., Quality of Informed Consent in Cancer Clinical Trials: A CrossSectional Survey, 358 LANCET 9295 (2001).

62. Id.

63. Id.

64. Id. 
documented that patients from racial and ethnic minorities have particular difficulties understanding clinical trials. ${ }^{65}$

Nonetheless, patients in many clinical trials, even Phase I trials, probably do receive benefits. Patients are monitored closely, perhaps more closely than they would be outside of the trial setting. Clinical trials sponsored by the NIH or by major cancer networks are designed on the basis of state-of-the-art knowledge about available options for patients. The treatment teams involved in such trials are likely to be highly experienced and may be better able to manage side effects and disease symptoms. Finally, drugs or medical devices that have not yet received market clearance from the Food and Drug Administration ("FDA") will typically be provided free of charge, or in some cases at the cost of production, which may be a significant cost savings. ${ }^{66}$ The advantages are well documented for cancer therapy involving children, where participation rates are far higher than the estimated three to five percent rate of participation for adults with cancer. ${ }^{67}$ The results demonstrate higher success rates in treating children with cancer and better development of cancer therapies for children compared to cancer treatment for adults. ${ }^{68}$

Despite the fact that clinical trials involving patients with cancer typically offer experimental drugs without charge, patients (or their health insurers) generally are expected to pay all other charges of treatment received in the clinical trial. ${ }^{69}$ Patients are billed for the costs of administering the drug; the costs of diagnostic studies required to stage disease or assess disease progression; the costs of any hospitalizations, radiation therapy, or surgery; and the costs to treat any side effects or adverse reactions to therapy. ${ }^{70}$ The exceptions to these patient responsibilities are the costs of data collection or assessments required solely for the study itself and for monitoring therapy. ${ }^{71}$ Patients entering clinical trials are advised that they will be responsible for costs, often without accurate estimates of what those costs might be because of expenses related to side effects, adverse reactions, or patients' responses to

65. Elmer E. Huerta \& Everly Macario, Communicating Health Risk to Ethnic Groups: Reaching Hispanics as a Case Study, 25 J. NAT'L CANCER INST. MONOGRAPHS 23 (1999). See also L. Ellington et al., Decision Making Needs for Randomized Clinical Trial Participation Among Hispanics, 10 CANCER CONTROL 84 (2003) (arguing Hispanic patients make decisions about participation based on the quality of the relationships they have with providers).

66. For a discussion of the costs of care for patients enrolled in clinical trials, see Bruce H. Fireman et al., Cost of Care for Patients in Cancer Clinical Trials, 92 J. NAT'L CANCER INST. 136 (2000).

67. Jane E. Brody, Ferreting for Facts in the Realm of Clinical Trials, N.Y. TIMES, Oct. 15,2002 , at F7.

68. See, e.g., Chan Ka Way, Acute Lymphoblastic Leukemia 32 CURRENT PROBS. PEDIATRIC ADOLESCENT HEALTH CARE 40 (2002).

69. Fireman et al., supra note 66.

70. Id.

71. Id. 
therapy may vary. Patients are also advised that their insurers may not cover the costs of participating in clinical trials. ${ }^{72}$

Indeed, insurers frequently deny coverage of therapy deemed "experimental" or "investigational." 73 Coverage can generally be negotiated for interventions that the patient would likely incur as part of disease managementsuch as diagnostic studies needed to stage disease - whether or not the patient is in a clinical trial. In addition, coverage is generally provided for interventions that are very similar to standard therapy, such as modification of chemotherapy regimen. Also, coverage is typically provided for management of adverse reactions to experimental treatment. Expensive, novel interventions are most likely to be ones for which insurers have the incentive to delay decisions to allow coverage. A very high profile example of an intervention deemed experimental and hence, denied by many insurers was myoablative chemotherapy with stem cell support for breast cancer, where coverage was refused whether or not the patient was participating in a clinical trial. These refusals and legal challenges to them are discussed in Part five (V) below.

When patients' health insurance does not cover participation in clinical trials, both individual and collective problems may arguably result. On the individual level, patients may incur unforeseen and non-reimbursed costs for health care. They may be denied care that might actually prove beneficial to them. Care studied in a clinical trial might also be offered off-study. Refusal by insurers to pay for care in the study might create incentives for patients to seek care off-study. The pattern thus created would be counterproductive both for patients and for health care generally. Patients may receive the care in a less structured setting in which they are not as well monitored. Consequently, because the care is not formally characterized as investigational, it may come to be regarded as established therapy even though there is not yet sufficient data to support that conclusion. However, because the care is being delivered off-study and not as research, clinicians will be deterred from collecting or publishing systematic data about side effects and outcomes. Collecting such data would require characterizing the delivery of the care as "research." Moreover, patients provided care off-study are not randomized, and apparently promising outcomes may be only anecdotal results of confounding factors rather than of the care itself. The upshot may be the worst of both worlds: patients receive care erroneously styled as "treatment" under circumstances where scientifically useful evaluative data is not and cannot be collected.

In the fall of 2000 , Medicare began covering routine costs for patients participating in specified clinical trials, as well as reasonable and necessary

72. See, e.g., NCI, Cancer Facts, at http://cis.nci.nih.gov/fact/7_41.htm (last visited Feb. 5,2004 ) (answering questions for patients contemplating bone marrow transplants).

73. See, e.g., NCI, ClINICAL TRIALS AND INSURANCE COVERAGE - A RESOURCE GUIDE: SUMMARY, at http://www.nci.nih.gov/clinicaltrials/understanding/insurance-coverage (last visited Mar. 16, 2004). 
treatment for complications arising from participation in clinical trials. ${ }^{74}$ In extending this coverage, Medicare acted on the recognition that there was often little reliable data as to whether new therapies are safe or effective in the Medicare population. Extending coverage to patients in clinical trials meeting specified scientific criteria would help to remedy that gap, thus enhancing coverage decisions generally. For purposes of this coverage, "routine costs" were defined to include all of the items and services otherwise available to Medicare patients. Thus, routine costs would include hospitalization or costs for administration of drugs, but not the drugs themselves, to the extent that Medicare does not include drug coverage. Services specified as routine costs are conventional care, care required to administer the experimental therapy or prevent complications, and reasonable and necessary care for the diagnosis or treatment of complications. Routine costs exclude the costs of the test item (drug or medical device) itself. Also excluded are services provided solely for data collection and analysis rather than the patient's clinical needs, such as additional scans for monitoring disease progression and efficacy of the test item but not used for clinical management. Any item customarily provided free of charge for patients participating in the clinical trial (whether or not covered by Medicare) is also excluded as a routine cost.

For care to be covered, the purpose of the trial must be an evaluation of a service that falls within a Medicare benefit category. Trials must have therapeutic intent and not be designed to test toxicity or disease pathophysiology exclusively. Trials of therapeutic interventions must enroll only patients with a diagnosed disease. Healthy volunteers may be included as controls in tests of diagnostic interventions. Additional criteria that clinical trials qualifying for coverage must meet include: (1) the principal purpose of the trial must be to test whether the intervention potentially improves the participants' health outcomes; (2) the trial must be well-supported by available scientific and medical information or it must be intended to clarify or establish the health outcomes of interventions already in common clinical use; (3) the trial must not unjustifiably duplicate existing studies; (4) the trial design must be appropriate to answer the research question being asked in the trial; (5) the trial sponsor must be a credible organization or individual capable of executing the proposed trial successfully; (6) the trial must comply with federal regulations relating to the protection of human subjects; and (7) all aspects of the trial must be conducted according to the appropriate standards of scientific integrity.

These criteria aim primarily to ensure the scientific merit of the study. The trial must be designed to answer a research question, and duplication of results must be avoided. The criteria are also aimed at ensuring that the trial

74. The following discussion can be attributed to the Medicare coverage document. See Ctrs. for Medicare \& Medicaid Servs., National Coverage Determinations, at http://www.cms .hhs.gov/ncd/searchdisplay.asp?NCD_ID=1\&NCD_vrsn_num=1 (last visited July 28, 2003). 
meets core ethical standards for research: scientific integrity and the protection of human subjects. To be sure, the research must also have a therapeutic purpose; but therapeutic research that is not first rate science will not qualify for coverage under the Medicare standards. Clinical trials sponsored by the NIH, the Centers for Disease Control and Prevention ("CDC"), the Agency for HealthCare Research and Quality ("AHRQ"), the HealthCare Financing Administration ("HCFA," now "CMS"), the Department of Defense ("DOD"), and the Department of Veterans Affairs ("VA") are deemed to automatically meet these additional criteria. Trials conducted by centers or cooperative groups, such as the Southwest Oncology Group ("SWOG"), supported by the listed federal entities also automatically meet the additional criteria. Trials conducted under an investigational new drug application reviewed by the FDA likewise automatically qualify. Other trials must certify that they meet the Medicare criteria and are enrolled in a Medicare clinical trials registry. Further development and review of these criteria is assigned to a multi-agency federal panel convened by the AHRQ. These procedures are designed to ensure scientific quality and research integrity without the need for study-bystudy review.

Some insurers in the private market have adopted policies that parallel the approach taken by Medicare. Others continue to refuse to cover any therapy deemed experimental. State legislatures have entered the arena by enacting coverage mandates, but some of these mandates extend coverage far more broadly than the Medicare criteria. These issues are the subject of Part four (IV).

\section{STATUTORY APPROACHES TO COVERAGE}

Within the past ten years, many states have mandated insurance coverage for some care treated as experimental under insurance plans. The majority of states now have coverage mandates for some off-label drug use. ${ }^{75}$ Fewer states mandate coverage for certain patients participating in clinical

75. ALA. CODE § 27-1-10.1 (2003); ARIZ. REV. STAT. § 20-826(R) (2003); ARK. CODE ANN. § 23-79-147(b) (Michie 2003); CAL. INS. CODE § 10123.195(a)(2)(B) (Deering 2003); CONN. GEN. STAT. ANN. § 38a-492b (West 2003); GA. CODE ANN. § 33-24.59.11 (2003); 215 ILl. COMP. STAT. 5/370-r (2003); IND. CODE ANN. \& 27-8-20-7 (Michie 2003); KAN. STAT. ANN. $\S$ 40-2,168 (2002); LA. REV. STAT. ANN. § 22:230.4(a) (West 2003); ME. REV. STAT. ANN. tit. 24, § 2320-F (2003); MD. CODE ANN., INS. § 15-804 (2003); MASS. GEN. LAWS ch. 175, § 47K (2003); MICH. COMP. LAWS $§ 500.3406 q$ (2003); MINN. STAT. § 62Q.525 (2002); Miss. CODE ANN. § 83-9-8 (2003); NEV. REV. STAT. \$ 689A.0404 (2003); N.H. REV. STAT. ANN. § 415:6g(1) (2002); N.J. STAT. ANN. § 17B:26-2.1g (West 2003); N.C. GEN. STAT. § 58-51-59 (2003); N.D. CENT. CODE § 26.1-36-06.1 (2003); OHIO REV. CODE ANN. § 1751.66(A) (Anderson 2002); OKLA. STAT. tit. 63, § 1-2604 (2002); OR. REV. STAT. § 743.697(1) (2001); R.I. GEN. LAWS § 27-55-2(a) (2002); S.C. CODE ANN. § 38-71-275(A) (Law. Co-op. 2002); S.D. CODIFIED LAWS § 58-17-101 (Michie 2003); TENN. CODE ANN. § 56-7-2352 (2003); TEX. INS. CODE ANN. § 21.53M (Vernon 2003); VA. CODE ANN. § 38.2-3407.5(A) (Michie 2003). 
trials. ${ }^{76}$ As state law governing insurance, these mandates are preempted by the Employee Retirement Income Security Act ("ERISA") for employee welfare plans not deemed to be insurance; thus, state mandates do not extend to employers who self-insure their health plans. ${ }^{77}$ Some employers nonetheless may follow state mandates voluntarily. As the descriptions below indicate, however, the mandates vary in the scientific basis they require. The more indiscriminate mandates arguably exacerbate the confusion between research and treatment. These mandates may lead patients to demand care that they believe is needed treatment, even though it may not be beneficial, supported by evidence, or come under policy language covering "reasonable and necessary" care.

\section{A. Coverage Mandates for Off-Label Drug Use}

FDA approval of new drugs for marketing includes labeling with indication, dosage, and patient population. Labeling information is based on data supporting safety and efficacy of the drug for the indication in the patient population. ${ }^{78}$ Once a drug is marketed, physicians are legally permitted to prescribe it for different patient populations, at different dosages, or for new indications. In such situations, the drug is used "off-label." Drugs used to treat cancer are frequently employed in off-label fashion. ${ }^{79}$ This practice is reasonable because cancer treatment evolves rapidly, and a drug initially found effective against one tumor type might also have promise against another. The alternative would be to require FDA approval for each new indication, a cumbersome and time-consuming process that would introduce substantial delays. On the other hand; indiscriminate off-label use risks subjecting patients to highly toxic therapy that has not undergone rigorous

76. ARIZ.REV.STAT. ANN. §§ 20-826.01(A)(6), (7) (2003); CAL. INs. CODE § 10145.4(a) (2003); ConN. GEN. STAT. ANN. § 38a-504a (West 2003); GA. CODE ANN. § 33-24-59.1(a)(2) (2003); 215 ILL. COMP. STAT. ANN. 5/356-y(c)(2) (2003); LA. REv. STAT. ANN. § 22.230.4(E)(2) (West 2003); ME. REV. STAT. ANN. tit. 24-A, § 4310(1)(A) (2003); MD. CODE ANN., INS. § 15827(e)(1)(2003); MASS. GEN.LAWS ANN. ch. 175, § 110L(c)(2), (4)(West 2003); Mich. COMP. LAWS $\$ 550.1929(7)$ (West 2003); Mo. ANN. STAT. \$ 376.429(1) (West 2003); NEV. REV. STAT. ANN. 689A.04033 (Michie 2003); N.H. REV. STAT. ANN. § 415:18-1(II) (2003); N.M. STAT. ANN. § 59A-22-43(A) (Michie 2003); N.C. GEN. STAT. § 58-3-255(a)(1) (2003); VT. STAT. ANN. tit. 8, § 4088b(a)(3) (2003); VA. CODE ANN. § 38.2-3418.8(D) (Michie 2003).

77. 29 U.S.C. $\$ 1144(2003)$.

78. See FOOD\& DRUG ADMIN., GUIDANCE FOR INDUSTRY: CLINICAL STUDIES SECTIONOF LABELING FOR PRESCRIPTION DRUGS AND BIOLOGICS-CONTENT AND FORMAT (May 2001 draft), available at http://www.fda.gov/cder/guidance/1890dft.pdf

79. Nat'l Cancer Inst., Understanding the Approval Process for New Cancer Drugs: $Q \& A$ : Off-Label Drugs, at www.cancer.gov/clinicaltrials/understanding/approval-process-for-cancerdrugs/page5 (last visited July 16, 2003). For a policy evaluating reimbursement on the basis of each type of use, see, e.g., the Montana Blue Cross/Blue Shield web site, at http://mt1-bcbs. bcbsmt.com/bsd/MedicalPolicy.nsf/PoliciesByTitleView?OpenView\&Count=300 (last visited Feb. 7, 2004). 
scientific evaluation. Thus, the NCI both recognizes and urges caution in offlabel use.$^{80}$ It is estimated that at least half of all cancer patients receive some off-label treatment. ${ }^{81}$ Estimates of off-label use are higher for children, because drugs are frequently approved for adults without having been tested in children. ${ }^{82}$

More than thirty states currently mandate at least some coverage for offlabel uses of drugs. ${ }^{83}$ Some states apply the mandate to off-label use in cancer treatment only, ${ }^{84}$ while others apply the mandate generally ${ }^{85}$ Still others apply the mandate only to drugs used in treating life-threatening or chronic and seriously debilitating conditions. ${ }^{86}$ These mandates typically leave other coverage limitations undisturbed, such as deductibles and co-payments or restrictions on the use of non-formulary drugs. ${ }^{87}$

80. Nat'l Cancer Inst., supra note 79.

81. T. Laetz \& G. Silberman, Reimbursement Policies Constrain the Practice of Oncology, 266 JAMA 2996 (1991).

82. Sharon Conroy et al., Unlicensed and Off Label Drug Use in Acute Lymphoblastic Leukaemia and Other Malignancies in Children, 14 ANNALS ONCOLOGY 42 (2003).

83. Nat'l Cancer Inst., Understanding the Approval Process for New Cancer Drugs: Summary, at www.cancer.gov/clinicaltrials/understanding/approval-process-for-cancer-drugs/ page5\#anchor-wha-15227 (last visited July 18, 2003) (indicating that thirty-nine states have such coverage requirements, by statute, administrative regulation, or non-legislative agreement). However, this count may be an overestimation. Several listed states provide for review of coverage denials but do not appear to mandate coverage for off-label drugs. One listed state, Kentucky, has repealed its mandate. KY. REV. STAT. ANN. § 304.17A-137 (repealed 2002). Also, Louisiana covers off-label uses only within clinical trials. LA. REV. STAT. ANN. $\S 22: 230.4$ (a) (West 2003). Thirty states currently have statutory mandates for coverage of at least some off label uses. See supra note 75.

84. ARIZ. REV. STAT. § 20-826(R) (2003); ARK. CODE ANN. \& 23-79-147(b) (Michie 2003); CONN. Gen. STAT. ANN. \& 38a-492b (West 2003); 215 ILL. COMP. STAT. 5/370-r (2003); KAN. STAT. ANN. \& 40-2,168 (2002); ME. REV. STAT. ANN. tit. 24, \& 2320-F (West 2003); MinN. STAT. \& 62Q.525 (2002); Miss. CODE ANN. \& 83-9-8 (2003); Nev. REV. STAT. § 689A.0404 (2003); N.C. GEN. STAT. \& 58-51-59 (2003); OKLA. STAT. tit. 63, § 1-2604 (2002); R.I. GEN. LAWS § 27-55-2(a) (2002); S.C. CODE ANN. § 38-71-275(A) (Law. Co-op. 2002); TENN. CODE ANN. § 56-7-2352 (2003); VA. CODE ANN. \$ 38.2-3407.5(A) (Michie 2003).

85. ALA. CODE § 27-1-10.1 (2003); IND. CODE ANN. § 27-8-20-7 (Michie 2003); MD. CODE ANN., INS. § 15-804 (2003); MASS. GEN. LAWS ch. 175, \& 47K (2003); N.H. REV. STAT. ANN. § 415:6-g(1) (2002); N.J. STAT. ANN. § 17B:26-2.1g (West 2003); N.D. CENT. CODE, § 26.1-36-06.1 (2003); OHIO REV. CODE ANN. § 1751.66(A) (Anderson 2002); OR. REV. STAT. $\S 743.697$ (1) (2001).

86. CAL. INS. CODE § 10123.195(a)(2)(B) (Deering 2003); MiCH. COMP. LAWS $\S$ 500.3406q (2003); TEX. INS. CODE ANN. $\$ 21.53$ M (Vernon 2003). Cf. S.D. CodifiEd LAWS $\S 58-17-101$ (Michie 2003) (including limit only to cancer and life-threatening conditions).

87. ARIZ. REV. STAT. \& 20-826(R) (2003); CAL. INS. CODE \& 10123.195(h) (Deering 2003); ME. REV. STAT. ANN. tit. 24, § 2320-F(2)(E) (West 2003); N.H. REV. STAT. ANN. § 415:6-g(3) (2002); OHIO REV. CODE ANN. § 1751.66(D)(4) (Anderson 2002); R.I. GEN. LAWS $\S 27-55-2(d)(2002)$. 
Many states require at least some verification that use of the drug has been scientifically validated. ${ }^{88}$ Recognized validation methods include drug compendia such as the United States Pharmacopeia Drug Information, the American Medical Association Drug Evaluations, or the American Hospital Formulary Service Drug Information; or publications in the peer-reviewed literature. ${ }^{89}$ These statutes provide patients with assurance that coverage will not be denied for beneficial treatment merely because sufficient evidence of safety and efficacy has not been provided to the FDA to authorize changes in the drug's labeling. To the extent validation in the scientific literature is required, coverage is limited to therapy that has been evaluated for safety and efficacy. On the other hand, if the quality of scientific evidence is low, the mandates open the door to coverage for therapy of uncertain efficacy.

The quality of scientific evidence required in the mandates varies significantly. Some states require only a single peer-reviewed article, without further discussion of the required strength of the scientific evidence. In theory, the article could be a case report of the drug's use in one patient or in

88. The Arizona statute has perhaps the most complete explanation of what might be considered scientific validation. In addition to medical reference compendia, Arizona will recognize data if:

(a) At least two articles from major peer reviewed professional medical journals have recognized, based on scientific or medical criteria, the drug's safety and effectiveness for treatment of the indication for which the drug has been prescribed; (b) No article from a major peer reviewed professional medical journal has concluded, based on scientific or medical criteria, that the drug is unsafe or ineffective or that the drug's safety and effectiveness cannot be determined for the treatment of the indication for which the drug has been prescribed; [and] (c) The literature meets the uniform requirements for manuscripts submitted to biomedical journals established by the international committee of medical journal editors or is published in a journal specified by the United States department of health and human services as acceptable peer reviewed medical literature pursuant to section $186(\mathrm{t})(2)(B)$ of the social security act, 42 U.S.C. $\S$ $186(\mathrm{t})(2)(\mathrm{B})(2003)$.

ARIZ. REV. STAT. § 20-826(s)(2) (2003).

Other states require validation in at least two peer-reviewed articles. MISS. CODE ANN. § 83-9-8 (2003); NEV. REV. STAT. 689A.0404 (2003); S.C. CODE ANN. § 38-71-275(C)(3) (Law. Co-op. 2002). Some states, however, require as little as validation in one peer-reviewed article. IND. CODE ANN. § 27-8-20-7 (Michie 2003); N.J. REV. STAT. § 17B:26-2.1g (2003). Yet others refer generally to the "medical literature," without specifying numbers of articles or size of studies. MASS. ANN. LAwS ch. 175, § 47K (Law. Co-op. 2003); TENN. CODE ANN. § 567-2352(c)(1) (2003). Oregon requires the "majority" of the medical literature. OR. REV. STAT. $\S 743.697(1)$ (b) (2001). Virginia notes specifically that "peer-reviewed medical literature does not include publications or supplements to publications that are sponsored to a significant extent by a pharmaceutical manufacturing company or health carrier." VA. CODE ANN. $\S 38.2-$ 3407.5(C) (Michie 2003). Even in the peer-reviewed literature, studies may vary importantly in the quality of the evidence they provide for a given therapeutic intervention. Some publications may consist of single case reports or case series with historical controls, thought to be evidence of lesser quality than randomized clinical trials. See Medicare Coverage Advisory Comm., supra note 7.

89. See, e.g., CONN. GEN. STAT. ANN. § 38a-492b (West 2003). 
a small series of patients. Moreover, blanket coverage mandates do not encourage systematic collection of further scientific data about the efficacy of therapy, although rigorous studies may take place in the clinical context.

Two solutions to these difficulties might be suggested. The first is to limit these coverage mandates to off-label uses that have reached sufficient scientific validation to appear in one of the recognized pharmaceutical compendia. A second possibility, designed especially to gather good scientific evidence of therapeutic safety and efficacy, would be to cover off-label uses in appropriately-designed clinical trials, as illustrated by many of the clinical trials involving children with cancer.

\section{B. Coverage Mandates for Participation in Clinical Trials}

Since 1998, seventeen states have enacted statutes extending coverage mandates for cancer patients in at least some clinical trials. ${ }^{90}$ Despite the growth of such statutes, only one law review has regarded the development as a "note"-worthy innovation in state law. ${ }^{91}$ Even law reviews in Connecticut, the home of much of the insurance industry, left the development unremarked. One early article, published before the movement towards such statutes gathered full steam, argued for limited coverage of patients participating in trials meeting certain standards of clinical integrity, scientific integrity, and fiscal soundness. ${ }^{92}$ This discussion saw the primary purpose of such coverage as a response to patients' desires for last chance therapy, and the secondary purpose as the development of better data about new therapies.

The statutory coverage mandates actually enacted vary in important respects with regard to patients covered, type of clinical trial, costs covered, mechanism of operation, and apparent rationale. Georgia's statute, the very first, only covers participation in clinical trials for children diagnosed with cancer. ${ }^{93}$ Most other statutes are limited to patients who have been diagnosed with cancer and meet the qualifications for participating in the trial. ${ }^{94}$ Nevada has also extended the mandate to patients enrolled in clinical trials for treatment of chronic fatigue syndrome. ${ }^{95}$ Mandates in Maine, Maryland, New Hampshire, and North Carolina extend even more broadly to patients in clinical trials for any life-threatening condition. ${ }^{96}$

90. See statutes cited, supra note 76.

91. Lesley C. Murphy, Health and Welfare: Mandatory Health Insurance Coverage for Cancer Clinical Trials, 33 MCGEORGE L. REV. 314, 314-22 (2002).

92. Mary Ader, Investigational Treatments: Coverage, Controversy, and Consensus, 5 ANN. HEALTH L. 45, 45-60 (1996).

93. GA. CODE ANN. § 33-24-59.1(a)(2) (2003).

94. See, e.g., CAL. INS. CODE $§ 10145.4($ a) (West 2003).

95. NEV. Rev. StAT. ANN. 689A.04033 (Michie 2003).

96. See ME. Rev. STAT. ANN. tit. 24-A, §4310(1)(A) (2003); MD. Code ANN., INS. § 15827(e)(1)(ii) (2003); N.H. REV. STAT. ANN. § 415:18-1(II) (2003); N.C. GEN. STAT. § 58-3255(a)(1) (2003). 
States have different limits on the phases of clinical trials covered. Covering all phases (Phases I-IV) are California, Maryland, Massachusetts (Phase I only at an academic medical center or affiliated facility), New Hampshire (Phase I and II on a case-by-case basis only), Vermont (all Phases limited to approved centers), and Virginia (Phase I on a case-by-case basis only). ${ }^{97}$ Illinois, Louisiana, Nevada, and New Mexico only cover Phases IIIV. ${ }^{98}$ Connecticut only covers participation in Phase III trials, ${ }^{99}$ while Missouri covers Phases III and IV. ${ }^{100}$ Statutes covering Phase I trials require insurers to pay for interventions that do not necessarily have the primary goal of treating the patient at hand. Statutes limiting coverage to the later phases focus more directly on trials in which therapeutic goals are paramount.

Many, but not all, of these statutes also limit the mandate explicitly to trials with some anticipated benefit for the patient, although they formulate this requirement in different ways. Some statutes require a determination that participation offers the possibility of clinical benefit to the patient. ${ }^{101}$ Other statutes specify that qualifying trials must have therapeutic intent and end points not defined exclusively to test toxicity. ${ }^{102}$ Others require a reason to believe that the proposed treatment is at least as effective as, or better than, available treatment. ${ }^{103}$ Louisiana covers trials with therapeutic or palliative intent for prevention or early detection of cancer. ${ }^{104}$ In a statute in effect from 2000-2003, Illinois required that the care be both medically appropriate and that it not yet have been determined to be safe, effective, or otherwise medically appropriate or necessary. ${ }^{105}$ Perhaps reflecting an error in drafting, Missouri requires that "there must be equal to or superior, noninvestigational treatment alternatives and the available clinical or preclinical data must provide a reasonable expectation that the treatment will be superior to the

97. CAL. INS. CODE § 10145.4(a) (West 2003); MD. CODE ANN., INS. § 15-827(e)(1) (2003); MASS. GEN. LAWS ANN. ch. 175, § 110L(c)(2), (4) (2003); N.H. REV. STAT. ANN. § 415:18-1(II) (2003); VT. STAT. ANN. tit. 8, § 4088b(a)(3) (2003); VA. CODE ANN. § 38.23418.8(D) (Michie 2003).

98. 215 Ill. Comp. Stat. ANn. 5/356-y(c)(2) (West 2003); LA. REV. Stat. ANN. § 22.230.4(E)(2) (West 2003); NEV. REV. STAT. ANN. 689A.04033 (Michie 2003); N.M. STAT. ANN. § 59A-22-43(A) (Michie 2003); N.C. GEN. STAT. § 58-3-255(a)(1) (2003).

99. Conn. Gen. Stat. AnN. §38a-504a (West 2003). Perhaps the assumption is that Phase IV, post-marketing trials, will be covered in any event, so their addition is not necessary.

100. Mo. ANN. STAT. § 376.429(1) (West 2003).

101. CAL. INS. CODE $\S 10145.4$ (a) (West 2003) (insured's physician determines "meaningful potential to benefit").

102. Id.; MASS. GEN.LAwS ANN. ch. $175, \S 110 \mathrm{~L}$ (c)(9) (West 2003) (adds that there must be a reasonable expectation of a medical benefit commensurate with the risks of participation).

103. ARIZ. REV. STAT. ANN. §§ 20-826.01(A)(6)-(7) (West 2003); MD. CODE ANN., INS. $\S \S 15-827$ (e)(4)-(5) (2003); NEV. REV. STAT. ANN. 689A.04033.1(d)-(e) (Michie 2003); N.H. Rev. STAT. ANN. § III(b) (2003); VA. CODE ANN. §§ 33.2-3418.8(G)(1)-(2) (2003). If investigational treatment did not meet this standard, would the clinical trial be ethical?

104. LA. REV. StAT. ANN. §§ 22:230.4(E)(1)-(2) (West 2003).

105. 215 ILL. COMP. STAT. ANN. $\S \S 5 / 356 y(a)$, (c)(3) (repealed 01/01/2003). Illinois also limited the coverage mandate to $\$ 10,000$ annually. Id. $\S 5 / 356 y(a)$. 
noninvestigational alternatives." ${ }^{106}$ More clearly, Maine requires "meaningful potential for significant clinical benefit." 107 North Carolina requires that participation in the trial be medically indicated and more preferable for the patient than standard care, although it is difficult to see how a trial would be ethical if participation in it were medically indicated because one of the options is already known to be better than standard care. ${ }^{108}$

As additional protection for patients, some states' statutes add provisions about the qualifications of the physicians providing the care. Arizona, Louisiana, Nevada, New Hampshire, New Mexico, and Virginia all require that the care be within the scope of practice, experience, and training of the physicians involved. ${ }^{109}$ Massachusetts, Missouri, and North Carolina add that the physicians must treat a sufficient volume of patients in that area of medicine to maintain their expertise. ${ }^{110}$ Illinois' repealed statute required that the patient's primary care physician, if any, be involved in coordinating the care. ${ }^{111}$ Massachusetts and New Hampshire require that the patient give informed consent that meets current legal and ethical standards, ${ }^{112}$ and Nevada demands that the patient be informed of the procedure, alternative methods of treatment, and the risks associated with participation in the clinical trial. ${ }^{113}$

In addition to implementing medical provider guidelines, states employ a number of methods to ensure that covered trials meet scientific standards. The ones of these that are most stringent parallel Medicare's limit to trials approved by various federal agencies or the centers and cooperative groups they support. ${ }^{114}$ Maine limits the approving federal agencies to the Department of Health and Human Services, the NIH, and NIH-approved cooperative groups or centers. ${ }^{115}$ Arizona adds trials approved by a panel of experts in

106. Mo. ANN. STAT. \& 376.429(2) (West 2003).

107. ME. REV. STAT. ANN. tit. 24-A, § 4310(1)(c) (2003).

108. N.C. GEN. STAT. § 58-3-255(a)(1)(a) (2003). The exact language in the North Carolina statute reads: "medically indicated and preferable for that patient compared to available non-investigational treatment alternatives and ... have clinical and preclinical data that show the trial will likely be more effective for that patient than available noninvestigational alternatives." Id.

109. ARIZ. Rev. Stat. ANN. § 20-826.01(A)(5) (West 2003); LA. Rev. Stat. ANN. $\S$ 22:230.4(E)(5) (West 2003); NEV. REV. STAT. ANN. 689A.04033.1(c) (Michie 2003); N.H. REV. STAT. ANN. § 415:18-1(III)(c) (2003); N.M. STAT. ANN. § 59A-22-43(A)(7) (Michie 2003); VA. CODE ANN. § 38.2-3418.8(F) (Michie 2003).

110. MASS. GEN. LAWS ANN. ch. 175, § 110L(c)(3) (2003); Mo. ANN. STAT. § 376.429(2) (2003); N.C. GEN. STAT. § 58-3-255(a)(1)(c) (2003).

111. 215 ILL. COMP. STAT. ANN. § 5/356-y(c)(5) (repealed 2003).

112. MASS. Gen. LAWS ANN. ch. 175, § 110L(c)(6) (West 2003); N.H. ReV. STAT. ANN. $\S$ 415:18-1(VI) (2003).

113. NEV. REV. STAT. ANN. 689A.04033.1(g) (Michie 2003).

114. CAL. INS. CODE $\S 10145.4$ (c) (West 2003) (including trials of uses of nonexperimental drugs); ConN. GEN. STAT. § 38a-504b (2003); 215 ILL. COMP. STAT. ANN. § 5/356-y(c)(3) (repealed 2003); LA. REV. STAT. ANN. § 22:230.4(E)(3) (West 2003); NEV. REV. STAT. ANN. 689A.04033, 1(b) (Michie 2003).

115. ME. REV. STAT. ANN. tit. 24-A, § 4310(4) (West 2003). 
clinical research within academic health institutions in Arizona. ${ }^{116}$ Maryland, Massachusetts, Missouri, New Hampshire, and Virginia add trials approved by institutional review boards of institutions with multiple project assurance agreements with the Office of Protection from Research Risks of the NCI. ${ }^{117}$ Many states add the requirement that the trial receive institutional review board approval, required for protection of human subjects in research, despite the fact that this is already a requirement for any federally funded research. ${ }^{118}$

Like Medicare, these state statutes typically mandate coverage for routine costs of patient care: services provided outside a clinical trial as standard care, services provided for drug administration, services provided for disease staging and appropriate clinical monitoring, and services provided to treat side-effects and complications. ${ }^{119}$ Costs typically not covered are those that are associated with data collection and management, ${ }^{120}$ and costs that arguably should be covered if the goal of the statute were to advance medical knowledge. Another typical exclusion is non-clinical services, such as travel, housing, and companion expenses. ${ }^{121}$ Unapproved drugs or devices are not covered in Arizona and California. ${ }^{122}$ Another common exclusion is any costs covered by the trial for other enrolled patients, so insurers are not billed for costs the trial is willing to fund for other patients. ${ }^{123}$ Some of the statutes limit costs to in-state care, ${ }^{124}$ others to in-state care unless the care is only available out-of-state ${ }^{125}$ or out-of-state care is otherwise a covered benefit for standard

116. ARIZ. REV. STAT. §§ 20-826.01(A)(3)(f)-(g) (2003).

117. MD. CODE ANN., INS. § 15-827(e)(2)(v) (2003); MASS. GEN. LAWS ANN. ch. 175, $\S \S 110 \mathrm{~L}(\mathrm{c})(2),(4)$ (West 2003) (requiring that Phase I trials be conducted at an academic medical center or affiliated facility by clinicians with staff privileges); MO. REV. STAT. $\S$ 376.429.4(5) (2003) (statutory language requiring "appropriate assurance" rather than "multiple project assurance"); N.H. REV. STAT. ANN. § 415:18-1(III)(a)(5) (2003); VA. CODE ANN. § 38.2-3418.8(E)(5) (Michie 2003).

118. ARIZ. REV. STAT. § 20-826.01(A)(4) (2003); LA. REV. STAT. ANN. § 22:230.4(E)(4) (West 2003); N.M. STAT. ANN. § 59A-22-43(A)(6) (Michie 2003).

119. CAL. INS. CODE $\S 10145.4($ b)(1) (West 2003).

120. ARIZ. REV. STAT. $\$ 20-826.01(G)(5)(d)(2003)$; CAL. INS. CoDE $\$ 10145.4(b)(2)(C)$ (West 2003); LA. REV. STAT. ANN. § 22:230.4(A)(10)(b) (West 2003); ME. REV. STAT. ANN. tit. 24-A, § 4310(2) (West 2003); MD. CODE ANN., INS. § 15-827(a)(7)(ii)(3) (2003); MASS. GEN. LAWS ANN. ch. 175, § 110L(a)(7) (West 2003); N.H. REV. STAT. ANN. § 415:181(I)(h)(4) (2003); NEV. REV. STAT. ANN. 689A.04033.4(g) (Michie 2003); N.C. GEN. STAT. § 58-3-255(d) (2003); VA. CODE ANN. § 38.2-3418.8(C) (Michie 2003).

121. ARIZ. REV. STAT. § 20-826.01(G)(5)(c) (2003); CAL. INS. CODE § 10145.4(b)(2)(B) (West 2003); LA. REV. STAT. ANN. § 22:230.4(A)(10)(a) (West 2003); NEV. REV. STAT. ANN. 689A .04033.4(e)-(f) (Michie 2003); N.C. GEN. STAT. § 58-3-255(d) (2003).

122. ARIZ. REV. STAT. $§ 20-826.01(\mathrm{G})(5)$ (a)-(b) (West 2003) (excluding coverage on drugs or devices in Phase I trials and any investigational drugs or devices); CAL. INS. CODE $\S 10145.4(\mathrm{~b})(2)(\mathrm{A})$ (West 2003).

123. CAL. INS. CODE $\S 10145.4(\mathrm{~b})(2)(\mathrm{E})$ (West 2003).

124. ARIZ. REV. STAT. § 20-826.01(G)(5)(f) (2003); NeV. REV. STAT. § 689A.0404.1(f) (2003).

125. CAL. INS. CODE $\S 10145.4(d)$ (West 2003). 
treatment in the patient's insurance policy. ${ }^{126}$ Louisiana, Maryland, and Missouri have the additional requirement that any entity seeking coverage for clinical trials must maintain an up-to-date electronic post of the approved clinical trials, including the phase, approving entity, covered cancers, and estimated number of participants. ${ }^{127}$

Most of the statutes directly mandate benefits. However, the mandates may contain important exclusions. California, for example, excludes Medicare supplementary insurance and CHAMPUS, as well as insurance policies limited to certain types of benefits (for example, disability, vision only). ${ }^{128}$ Louisiana excludes plans paid for under Title XVII (SSI for the aged and disabled) or Title X (SSI for the blind) of the Social Security Act. ${ }^{129}$ Other statutes are structured as limits on what may be required as reimbursement for patients in clinical trials of cancer treatment; Arizona and New Mexico statutes function this way, and state explicitly that they provide only an administrative remedy, not a private right of action brought by a patient against an insurance corporation. ${ }^{130}$ The Michigan statute creates a fund to defray costs of patient participation, up to $\$ 5000$ per facility in Phase III or IV studies sponsored by the NIH; ${ }^{131}$ revenues for the fund come from fines paid for violations of the insurance code, a strategy that avoids ERISA preemption under the rationale of Blue Cross \& Blue Shield v. Travelers. ${ }^{132}$

Most importantly, statutes differ in apparent rationale. No statute sets out a legislative statement of purpose, so the reasoning behind the statutes must be gleaned from their structure and substance. From the account given above, it would appear that the principal aim is likely therapeutic value, or at least the minimum requirement that the trial be likely to provide the patient with prospects at least as good as those offered by standard therapy. Cost may have played a secondary role in the design of some statutes; for example, Vermont regards its mandate as a pilot program at approved medical centers and requires an analysis of cost data to determine the financial effect on insurance premiums. ${ }^{133}$ Deference to approval by federal agencies would seem to assure scientific merit, but this approach may also have been motivated by the effort to assure patients the best therapeutic options. Limited attention has been given to other scientific goals. Illinois wanted covered trials to be conducted for the primary purpose of determining safety and

126. N.M. STAT. ANN. § 59A-22-43(G) (Michie 2003).

127. LA. Rev. Stat. ANN. § 22:230.4(F) (West 2003); MD. Code ANN., Ins. § 15827(g)(1) (2003); Mo. REV. STAT. § 376.429(5) (2003).

128. CAL. INS. CODE $\S 10145.4$ (f) (West 2003).

129. LA. REV. STAT. ANN. § 22:230.4(C) (West 2003).

130. ARIZ. REV. STAT. § 20-826.01(D) (2003); N.M. STAT. ANN. § 594-22-43(E) (Michie 2003)

131. Mich. COMP. LaWs § 550.1929(7) (2003).

132. N.Y. State Conference of Blue Cross \& Blue Shield Plans v. Travelers Ins. Co., 514 U.S. 645 (1995).

133. VT. STAT. ANN. tit. $8, \S 4088 \mathrm{~b}(\mathrm{a})(4)(2003)$. 
efficacy, conducted at multiple centers, and aimed at the submission of peer reviewed publications. ${ }^{134}$ Massachusetts incorporates the Medicare requirement that the trial not unnecessarily duplicate existing studies, a criterion focusing on the scientific importance rather than the therapeutic efficacy of the trial. ${ }^{135}$ The differentiation between trial phases for coverage purposes may also convey the message that not all clinical trials are equally therapeutic in intent.

Otherwise, statutes leave the general impression that their legislative aim is to provide patients with the therapeutic benefits of clinical trials. This justification may leave patients who do not fit the entry criteria for the trials feeling that they have been dealt with unjustly because they are not receiving treatment that the state apparently believes is beneficial for others. Patients who do not meet strict entry criteria based on the science of the trials or who would like to participate in trials not covered by the statutes may wonder why they cannot take advantage of the therapy offered. Indeed, the one published commentary on these statutes, the assessment of the California statute in the McGeorge Law Review, illustrates this exact confusion about the rationale for the California mandate. ${ }^{136}$ On the one hand, the commentary praises the statute for the possibility that by encouraging participation in clinical trials it will help to develop better information about cancer treatment. ${ }^{137}$ On the other hand, it voices the concern that the statutory mandate will not cover therapy for a sufficient range of patients. ${ }^{138}$ The commentary criticizes the requirement that the clinical trial must have "meaningful potential" to benefit the patient as vague and likely to exclude too many patients and praises the statute for increasing the likelihood that desperate patients (such as a woman with metastatic breast cancer seeking high-dose chemotherapy) will have access to coverage. ${ }^{139}$

The limits in most statutes to trials approved by federal agencies will probably keep the actual coverage mandates within the bounds of rigorous scientific studies. Not all states impose these limits, however. It is important for legislatures to recognize that therapy alone cannot be the principal rationale for coverage, especially for patients participating in Phase I trials. Otherwise, statutory policy may contribute to the confusion held by many patients and members of the public that new therapies under investigation are the latest in established, beneficial care. This confusion has been especially apparent in the courts.

134. 215 ILL. COMP. STAT. §§ 5/356y(c)(3), (4), (6) (repealed 2003).

135. MASS. GEN. LAWS ch. 175, § 110L(c)(8) (2003).

136. Murphy, supra note 91.

137. Id. at 321.

138. Id. at 322.

139. Id. at 321. 


\section{High-DOSE CHEMOTHERAPY IN THE COURTS}

The confusion between investigational therapies and beneficial treatment has been manifested in the lawsuits brought by patients with breast cancer against insurance companies for denying coverage of high-dose chemotherapy. These lawsuits emerged in 1989, as initial encouraging reports appeared about the high-dose procedure and physicians began referring their patients to centers performing it. Patients were successful in many cases in gaining preliminary injunctions ordering coverage of the procedure and subsequently, summary judgment in their favor. Only when insurance contracts listed the procedure explicitly as non-covered, and sometimes not even then, did the courts uphold coverage denials.

Almost all of the cases denying coverage involved a determination of whether the patient could reasonably expect the care to be covered under their insurance contracts. ${ }^{140}$ Contracts create expectations, and courts interpreting contracts may have expectations about how similar contractual language is to be understood in other cases. In many of these cases, courts also determined that there had been sufficient testimony to support the efficacy of the therapy for the patient. Decisions about the efficacy of therapy, for the patient before the court, should have been case-specific, but as more of the cases were decided, courts cited prior holdings to support the conclusion that the therapy was beneficial to patients, thus multiplying the decisions' effects. The frequency of reported decisions diminished in the late 1990s, after reports questioning the evidentiary support for high-dose chemotherapy for breast cancer began to appear in the literature. Nevertheless, patients continued to experience success in litigation, with rulings as late as 2002 holding that it was arbitrary and capricious for insurers to deny the coverage as investiga-

140. A few of the cases were state law contract cases. The six reported state cases resolving the issue on the merits (five mandating the coverage, one as late as 2002) occurred in Arkansas, Colorado, Illinois, and Michigan. Am. Inv. Life Ins. Co. v. Butler, 65 S.W.3d 472 (Ark. Ct. App. 2002); Tepe v. Rocky Mtn. Health \& Med. Serv., 893 P.2d 1323 (Colo. Ct. App. 1994); O'Rourke v. Access Health, Inc., 668 N.E.2d 214 (Ill. App. Ct. 1996) (judgment for the insurer on plan language referring specifically to whether the federal Office of Technology Assessment had recommended coverage); Lubeznik v. HealthChicago, Inc., 644 N.E. $2 \mathrm{~d} 777$ (IIl. App. Ct. 1994); Mich. Affiliated Healthcare Sys., Inc. v. Peoples Life Ins. Co., No. 225067, 2001 Mich. App. LEXIS 1805 (Mich. Ct. App. Nov. 27, 2001); Taylor v. Blue Cross-Blue Shield of Mich., 517 N.W.2d 864 (Mich. Ct. App. 1994). An additional, recent state court decision resulted in a remand to the trial court for a decision on the merits. Pacino v. Med. Mut. of Ohio, Inc., No. 78757, 2001 Ohio App. LEXIS 5749, at *8-9 (Ohio Ct. App. Dec. 20, 2001) (rejecting trial court's finding that contract language was ambiguous; remanding for trial on the merits).

By far, the majority of the cases were either brought in federal court or removed to federal court because they involved coverage determinations under ERISA plans. In the cases under ERISA, contract interpretation is a question of law for the court. Coverage denials are reviewed under an arbitrary and capricious standard if discretion is reserved to the plan administrator; nearly all contemporary health insurance contracts reserve discretion in this way. Whether a contract provision is ambiguous is a question of law for the court; ambiguities are resolved against the insurer that has interests in denying the care. 
tional. These rulings have appeared in many circuits, no doubt encouraging patients in the twin beliefs about their contractual coverage and the benefits of care. ${ }^{141}$

In reaching their conclusions, courts have been signally impressed by the testimony of physicians recommending the care. Courts reason that if physicians recommend the care, it must be beneficial for their patients; therefore, it is irrational for insurers to deny coverage under an exception for care that is still under investigation and has not yet been demonstrated to be beneficial. In ruling against insurance plans, courts were especially impressed by their economic conflicts of interest, but almost never considered the possibility that physicians offering the procedure and testifying in its favor might have similar conflicts. ${ }^{142}$

The leading case ordering coverage of HDC/ABMT, Dozsa v. Crum \& Forster Insurance Co., was brought in 1989 by a patient with multiple myeloma. ${ }^{143}$ In that case, the plaintiff was granted a preliminary injunction ordering the therapy. ${ }^{144}$ To grant the injunction, the court was required to find that the plaintiff was likely to prevail on the merits, that failure to grant the relief would result in irreparable injury, that the insurer had not shown countervailing injury, and that the public interest was benefited by the grant of the relief. ${ }^{145}$ Like subsequent courts relying on this decision, the court had little difficulty in finding that these standards were met. The language in the plaintiff's insurance contract stipulated that coverage would not be allowed unless the therapy was "neither educational nor experimental in nature nor provided primarily for research purposes." 146 Prudential, the insurer, contended that:

A procedure or course of treatment does not become accepted in the profession until it has been demonstrated through clinical trials as being safe and effective for the condition. One of the best ways to determine the acceptance of such a procedure is through the published medical literature. Coverage usually commences after there is clear consensus in peer reviewed medical literature. ${ }^{147}$

141. For a description of how early decisions encouraged patients to go to court to seek coverage and how insurers responded by changing contract language, see Goepel v. Mail Handlers Benefit Plan, No. 93-3711, 1993 U.S. Dist. LEXIS 13346 (D.N.J. Sept. 23, 1993), vacated by 36 F.3d 306 (3d Cir. 1994).

142. See, e.g., Dozsa v. Crum \& Forster Ins. Co., 716 F. Supp. 131, 139 (D.N.J. 1989).

143. $I d$.

144. $I d$.

145. Id. at 137.

146. Id. at 134 (emphasis in original).

147. Id. at 135. Prudential had recently reviewed HDC/ABMT for myeloma and concluded it did not meet this standard because it was still "investigational." Dozsa, 716 F. Supp. at 135. At the time, there were two published papers in the literature, both published by a single physician, Bart Barlogie; no randomized clinical trials had been reported. Id. at 136 . Such case 
The court concluded that Prudential was applying a new standard for "experimental," which the court labeled "investigational," in reasoning this way. The plaintiff's treating oncologist had referred him to Johns Hopkins, where he was found to be a suitable candidate for the therapy. The court reasoned that if respected physicians were recommending the treatment, it must not be "experimental" within the medical community:

While it is true that a lack of peer reviewed medical literature might constitute some evidence of nonrecognition of the therapy throughout a doctor's profession, it is certainly not conclusive evidence. The four very talented expert witnesses in the present case were in disagreement on the question whether the literature concerning ABMT treatment for multiple myeloma constitutes backing of the treatment by a consensus in peer reviewed medical literature and thus supportive of coverage even under defendants' mistaken reading of the Plan language. It is unnecessary to decide that question one way or another because the undisputed testimony of Dr. Wingard and Dr. Davis establishes 1) as proposed for plaintiff the treatment was not educational or experimental in nature and was not to be provided primarily for research purposes and 2) it is commonly and customarily recognized throughout Dr. Wingard's profession as appropriate treatment of multiple myeloma. ${ }^{148}$

Many subsequent decisions involving patients with breast cancer likewise credited the testimony of treating oncologists over appeals to evidence-based medicine, as described in what follows.

The first reported decision ordering coverage of HDC/AMBT for a patient with breast cancer, Pirozzi v. Blue Cross/Blue Shield, ${ }^{149}$ was handed down in 1990. The plaintiff's plan excluded coverage for treatment that was an "experimental or clinical investigative procedure," but neither defined these terms nor reserved judgment about their application for the plan administrator. ${ }^{150}$ Construing what it regarded as ambiguous language against the insurer, the court credited the testimony of the treating oncologist that the procedure was Pirozzi's best chance for meaningful survival. As in Dozsa, the

series are subject to notorious selection bias. Medicare Coverage Advisory Comm., supra note 7. For the Medicare Coverage Advisory Committee's decision memo on HDC/ABMT for myeloma, see http://www.cms.hhs.gov/ncdr/memo.asp?id=10. For Medicare's ultimate decision to approve coverage in $\mathbf{2 0 0 0}$ for a subset of myeloma patients, after review of data from one randomized trial, see http://www.cms.hhs.gov/mcd/viewncd.asp?ncd_id=3530.1\&ncd_version $=5 \&$ show=all (last visited Feb. 8, 2004).

148. Dozsa, 716 F. Supp. at 138.

149. Pirozzi v. Blue Cross/Blue Shield of Va., 741 F. Supp. 586 (E.D. Va. 1990).

150. Id. at 588 . 
court reasoned that if the care was being used by major centers, it could not be investigational. ${ }^{151}$ In the next few years, decisions of this kind proliferated. In 1991, district courts in Connecticut, ${ }^{152}$ Maryland, ${ }^{153}$ Missouri, ${ }^{154}$ and New York $^{155}$ ordered coverage for HDC/AMBT. Over succeeding years, they were joined by the Second Circuit, ${ }^{156}$ the Ninth Circuit, ${ }^{157}$ and other federal courts in Alabama, ${ }^{158}$ the District of Columbia, ${ }^{159}$ Illinois, ${ }^{160}$ Indiana, ${ }^{161}$ Missouri, ${ }^{162}$

151. Id. at 591 .

152. Bucci v. Blue Cross/Blue Shield of Conn., Inc., 764 F. Supp. 728 (D. Conn. 1991). The Bucci court followed Dozsa and Pirozzi in crediting the testimony of treating oncologists over the technology assessments of Blue Cross/Blue Shield. It also found "logical, scientifically," the idea that the therapy would prove successful. Id. at 732.

153. Adams v. Blue Cross/Blue Shield of Md., Inc., 757 F. Supp. 661 (D. Md. 1991). Here the contract language read "not generally acknowledged as accepted medical practice by the suitable medical specialty practicing in Maryland, as decided by us." Id. at 663. Maryland oncologists were typically referring patients to Johns Hopkins for the procedure.

154. White v. Caterpillar, Inc., 765 F. Supp. 1418 (W.D. Mo. 1991), aff'd, 985 F.2d 564 (8th Cir. 1991). In White, the court credited the testimony of testifying oncologists over contract language that required following the guidance of reports of the Clinical Efficacy Assessment Project of the American College of Physicians and the Council on Scientific Affairs of the American Medical Association. Neither of these bodies had issued a determination that ABMT should be regarded as effective therapy for breast cancer as established. Id.

155. Kulakowski v. Rochester Hosp. Serv. Corp., 779 F. Supp. 710 (W.D.N.Y. 1991). Here, the contract exclusion read:

We will not provide benefits for any procedure or service which, in the sole judgment of the Blue Choice Medical Director, is experimental in nature. In addition, we will not provide benefits for medical treatments or procedures not proven to be safe and efficacious; nor will we provide benefits for ineffective or experimental surgical or medical treatments, or procedures, research studies or other experimental health care procedures under continued scientific testing and research with questions, in the sole judgment of the Blue Choice Medical Director, as to safety and efficacy.

$I d$. at 712 n.2. Despite the contract language reserving judgment to the plan, the court concluded that the insurer had applied a new and higher standard, credited the testimony of treating oncologists that the therapy was effective, and ruled that the coverage denial had been arbitrary and capricious. Id. at 717 . The witness the court found most impressive was the oncologist from the transplant program to which Kulakowski had been referred; his testimony reported the numbers of procedures he had performed and what he regarded as encouraging results from his series of patients. Id. at 713-14. The court cited White and Pirozzi in its conclusion. Id. at 715.

156. Zervos v. Verizon, N.Y., Inc., 277 F.3d 635 (2d Cir. 2002).

157. Simkins v. Nevadacare, Inc., 229 F.3d 729 (9th Cir. 2000).

158. Calhoun v. Complete Health, Inc., 860 F. Supp. 1494 (S.D. Ala. 1994).

159. Wilson v. Group Hospitalization \& Med. Servs., Inc., 791 F. Supp. 309 (D.D.C. 1992).

160. Frendreis v. Blue Cross Blue Shield of Mich., 873 F. Supp. 1153 (N.D. Ill. 1995); Duckwitz v. Gen. Am. Life Ins. Co., 812 F. Supp. 864, 867 (N.D. Ill. 1993) (holding HDC/ABMT not an "organ transplant" within the limits of plaintiff's policy).

161. Smith v. Office of Civilian Health \& Med. Program of the Unif. Servs., 884 F. Supp. 303 (S.D. Ind. 1994), rev'd, 97 F.3d 905 (7th Cir. 1996).

162. Henderson v. Bodine Aluminum, Inc., 70 F.3d 958, 960 (8th Cir. 1995) (holding that it would violate the Americans with Disabilities Act to cover effective therapy for some cancers but not effective HDC/ABMT for plaintiff's breast cancer). 
New York, ${ }^{163}$ North Carolina, ${ }^{164}$ South Carolina, ${ }^{165}$ Tennessee, ${ }^{166}$ Virginia,,${ }^{167}$ and Washington. ${ }^{168}$ Additionally, the Eleventh Circuit ruled that "experimental" was ambiguous as a matter of law and reversed and remanded a grant of summary judgment for the insurer, requiring a trial on the merits. ${ }^{169}$

These decisions typically followed Dozsa in crediting the testimony of treating oncologists over insurance companies' contentions that the therapy had not been validated scientifically. Courts seemed impressed by the fact that the treating oncologists had examined the patients, whereas the experts testifying for insurance companies typically had not examined the patients. ${ }^{170}$ The courts relied on the observation that major medical centers such as Johns Hopkins and Duke were offering the procedure and that community oncologists were referring their patients to these centers. Some courts explicitly borrowed the language typically used to state the standard of care in medical malpractice litigation -in the words of one court, whether the care is "generally acknowledged as accepted medical practice by the suitable medical specialty practicing in Maryland." ${ }^{171}$ Even when the language of the insurance contract granted unfettered discretion to plan administrators, some courts continued to find the denials arbitrary and capricious, in light of what they viewed as the patient's dire situation and the testimony of treating oncologists that the experimental treatment was the patient's only hope. Cases in this vein were decided as late as $2001 .{ }^{172}$ Sympathetic to patients, courts sometimes went to great lengths to read plan language against insurers. One particularly

163. Whitney v. Empire Blue Cross \& Blue Shield, 920F. Supp. 477, 480 (S.D.N.Y. 1996) (finding plaintiff benefited substantially from the treatment in February 1993, despite her death in July 1993; ordering coverage despite language reserving sole discretion to the insurer and a requirement of demonstrated benefit in the peer reviewed literature); Scalamandre v. Oxford Health Plans, Inc., 823 F. Supp. 1050, 1057 (E.D.N.Y. 1993) (HDC/ABMT "successfully extended [plaintiff's] life expectancy," from July 1991 to her death in January 1992); Kekis v. Blue Cross \& Blue Shield of Utica-Watertown, Inc., 815 F. Supp. 571 (N.D.N.Y. 1993) (following Kulakowski, Dozsa).

164. Hawkins v. Mail Handlers Benefit Plan, No. 1:94CV6, 1994 U.S. Dist. LEXIS 20671 (W.D.N.C. Jun. 28, 1994).

165. Gripkey v. Mail Handlers Benefit Plan, No. 3:94-378-0, 1994 U.S. Dist. LEXIS 20619 (D.S.C. Feb. 14, 1994).

166. Mashburn v. Mail Handlers Benefit Plan, No. 3:94-0549, 1994 U.S. Dist. LEXIS 19779 (M.D. Tenn. Aug. 4, 1994).

167. Wheeler v. Dynamic Eng'g, Inc., 850 F. Supp. 459 (E.D. Va. 1994); Bailey v. Blue Cross/Blue Shield of Va., 866 F. Supp. 277 (E.D. Va. 1994).

168. Bishop v. Office of Civilian Health \& Med. Programs of the Unif. Servs., 917 F. Supp. 1469 (E.D. Wash. 1996) (ordering coverage by CHAMPUS).

169. Dahl-Eimers v. Mutual of Omaha Life Ins. Co., 986 F.2d 1379 (11th Cir. 1993).

170. See Kulakowski v. Rochester Hosp. Serv. Corp., 779 F. Supp. 710, 713 (W.D.N.Y. 1991) ("Dr. Stankaitis had never seen or examined Mrs. Kulakowski, but based on a review of both her records and applicable medical literature, he opined that HDC/ABMT as proposed for her would be 'experimental' and, therefore, excluded from coverage under the contract.").

171. Adams v. Blue Cross/Blue Shield of Md., 757 F. Supp. 661, 669 (D. Md. 1991).

172. Smith v. Newport News Shipbuilding Health Plan, Inc., 148 F. Supp. 2 d 637 (E.D. Va. 2001). 
unusual line of reasoning was a Virginia court's determination that an insurance contract that excluded high dose chemotherapy "with" stem cell rescue could be read to cover the chemotherapy separately from the rescue. ${ }^{173}$ Another court reasoned that the procedure was not a "transplant" within the ordinary understanding of the term. ${ }^{174}$

One of the decisions favoring the plaintiff was particularly noteworthy for confusing clinical trials with therapy. In Dahl-Eimers v. Mutual of Omaha, the Eleventh Circuit remanded a district court's ruling refusing a preliminary injunction to the plaintiff pending a determination of the plaintiff's likelihood of success on the merits. ${ }^{175}$ The court held that the use of "experimental" in contract language was ambiguous as a matter of law. ${ }^{176}$ In Dahl-Eimers, the plaintiff sought to enter a Phase I/II trial, and the consent form specifically stated that the patient might not benefit from participation. ${ }^{177}$ The district court judge had concluded that the procedure therefore came within the contract exclusion for "experimental" care. ${ }^{178}$ The Eleventh Circuit, however, concluded "experimental" was ambiguous and that the plaintiff was entitled to a trial on the merits to determine whether participation in the trial came within the contract. Notably, the district court judge had vehemently expressed concerns that the lack of federal funding for patients participating in clinical trials adversely affected patient care and the development of medical knowledge. ${ }^{179}$ Dahl-Eimers may also be unique for the district court's observation of the possible conflict of interest on the part of oncologists seeking to enter patients into studies. ${ }^{180}$

Insurers responded to these decisions in part by changing contract language in an attempt to avoid rulings based on ambiguity. One strategy was to reserve discretion in coverage decisions to the plan administrator. Another strategy was to define "experimental" as applying specifically to the context

173. Bailey v. Blue Cross/Blue Shield of Va., 866 F. Supp. 277 (E.D. Va. 1994). The two therapies must be conjoined because the high dose chemotherapy oblates the patient's functioning bone marrow. Id.

174. Calhoun v. Complete Health, Inc., 860 F. Supp. 1494 (S.D. Ala. 1994).

175. See Dahl-Eimers v. Mut. of Omaha Life Ins. Co., 986 F.2d 1379 (11th Cir. 1993).

176. Id. at $1383-84$.

177. Dahl-Eimers v. Mut. of Omaha Life Ins. Co., 812 F. Supp. 1193, 1196 (N.D. Fla. 1992).

178. Id. at 1197-98.

179. In the words of the district court judge:

It is unfortunate that adequate funding for clinical trials of drugs and treatments for catastrophic illnesses is not available from the federal government. But such funding is quite limited, and is thinly spread among thousands of competing programs involving literally hundreds of various illnesses and diseases. Thoughtful people need to ponder how this problem can be fairly resolved. Id. at 1198.

180. Id. at 1197. 
of a clinical trial. ${ }^{181} \mathrm{~A}$ third option was to base approval on determinations by various evaluating organizations, such as the clinical assessment project of the American College of Physicians, the Council of Scientific Affairs of the American Medical Association, ${ }^{182} \mathrm{HCFA},{ }^{183}$ or the NIH. ${ }^{184}$ Insurance plans provided by the federal government for federal employees were particularly likely to be successful in referring coverage decisions to the standards of other federal agencies, such as Medicare. Federal plans also sometimes followed the Medicare standards in specifically excluding breast cancer as an indication for which HDC/ABMT was covered. ${ }^{185}$ Where the exclusion was not explicit, however, courts ruled in favor of federally-employed plaintiffs as well. ${ }^{186}$

Despite the criticisms in scientific literature of HDC/ABMT, courts continued to order coverage for breast cancer patients seeking high dose chemotherapy. The Ninth Circuit ruled in 2000 that a plaintiff could not reasonably have understood that an autologous bone marrow transplant was a "tissue transplant" within the exclusion language of her contract. ${ }^{187} \mathrm{~A}$ federal district court in Virginia granted a preliminary injunction for the plaintiff mandating the therapy so that she would not lose the window of opportunity for the procedure. ${ }^{188}$ In granting the injunction, the court discounted the need for Phase III studies to show an advantage for high dose

181. Lewis v. Trustmark Ins. Co., 182 F.3d 908 (4th Cir. 1999); Wolf v. Prudential Ins. Co. of Am., 50 F.3d 793 (10th Cir. 1995); Harris v. Mut. of Omaha Co., No. IP92-1089-C, 1992 U.S. Dist. LEXIS 21393 (S.D. Ind. Aug. 26, 1992).

182. See, e.g., Uhrich v. Caterpillar, Inc., No. 93C5271, 1993 U.S. Dist. LEXIS 16420 (N.D. Ill. Nov. 17, 1993).

183. See, e.g., Bechtold v. Physicians Health Plan of N. Ind., Inc., 19 F.3d 322 (7th Cir. 1994); Fuja v. Benefit Trust Life Ins. Co., 18 F.3d 1405 (7th Cir. 1994).

184. Lowery v. HealthChicago, Inc., No. 92 C7657, 1994 U.S. Dist. LEXIS 6380, at *3 (N.D. Ill. May 13, 1994).

185. Hawkins v. Mail Handlers Benefit Plan, No. 1:94CV6, 1994 U.S. Dist. LEXIS 20671 (W.D.N.C. June 28, 1994) (Mail Handlers plan); Jaecks v. Nat'l Ass'n of Letter Carriers Health Benefit Plan, No. 93C6855, 1993 U.S. Dist. LEXIS 16876 (N.D. Ill. Nov. 30, 1993); Reger v. Espy, 836 F. Supp. 869 (N.D. Ga. 1993); Goepel v. Mail Handlers Benefit Plan, No. 93-3711, 1993 U.S. Dist. LEXIS 13346 (D.N.J. Sept. 23, 1993), vacated by 36 F.3d 306 (3d Cir. 1994); Dodd v. Blue Cross \& Blue Shield Ass'n, 835 F. Supp. 888 (E.D. Va. 1993); Caudill v. Blue Cross-Blue Shield, No. 92-94-CIV-7-F, 1992 U.S. Dist. LEXIS 21448 (E.D.N.C. Aug. 24, 1992).

186. See Bishop v. Office of Civilian Health \& Med. Programs of the Unif. Servs., 917 F. Supp. 1469 (E.D. Wash. 1996); Gripkey v. Mail Handlers Benefit Plan, No. 3:94-378-0, 1994 U.S. Dist. LEXIS 20619 (D.S.C. Feb. 14, 1994); Wheeler v. Dynamic Eng'g., 850 F. Supp. 459 (E.D. Va. 1994); Mashburn v. Mail Handlers Benefit Plan, No. 3:94-0549, 1994 U.S. Dist. LEXIS 19779 (M.D. Tenn. Aug. 4, 1994); Smith v. Office of Civilian Health \& Med. Program of the Unif. Servs., 884 F. Supp. 303 (S.D. Ind. 1994); Hawkins, 1994 U.S. Dist. LEXIS 20671 (CHAMPUS coverage). In the Gripkey decision, the court concluded that the plaintiff had a reasonable likelihood of success on the merits because of the confused state of the decisions in other cases! 1994 U.S. Dist. LEXIS 20619, at *10.

187. Simkins v. Nevadacare, Inc., 229 F.3d 729 (9th Cir. 2000).

188. Smith v. Newport News Shipbuilding Health Plan, Inc., 148 F. Supp. $2 d 637$ (E.D. Va. 2001). 
treatment over conventional chemotherapy; it found the testimony of treating oncologists sufficient. ${ }^{189}$ In 2002, the Second Circuit ordered coverage of the therapy for a male patient with breast cancer, despite the patient's health plan's (Empire Health Choice) reliance on recent technology assessments. ${ }^{190}$ Also in 2002, a federal district court in Michigan rejected an insurer's decision that high dose chemotherapy was not indicated for someone with the patient's stage and type of disease, although it was covered for other indications. ${ }^{191}$ Finally, a state court in Arkansas rejected an insurer's insistence on data showing that high dose chemotherapy was superior to standard therapy before extending coverage. ${ }^{192}$ No reported cases in 2003 appear to have ruled on the issue.

To be sure, courts have not ruled uniformly in favor of plaintiffs seeking coverage for high dose chemotherapy. Insurance companies have prevailed in some cases, especially when contract language was absolutely explicit about excluding the procedure for breast cancer. Nonetheless, courts have been persuaded by the sympathetic situations of patients believing that court intervention was the patient's only hope. They have relied on the testimony of referring oncologists rather than on the published scientific literature. In so ruling, courts have reinforced the beliefs of patients that the care is both beneficial and covered. Courts have thus encouraged patients to form expectations in reliance on experts without sufficient scrutiny to determine whether this reliance is reasonably placed. Like legislatures, courts have not sufficiently distinguished therapeutic reasons from other moral reasons for providing care to patients when its efficacy is under investigation.

\section{CONCLUSION}

In mandating coverage for plaintiffs, courts sometimes noted public policy concerns. Judges referred to the financing of health care in America as being in a state of crisis ${ }^{193}$ and to the difficult judgments involved in funding expensive new modalities of care. ${ }^{194}$ These are indeed difficult questions. It is important to try to determine whether new therapeutic modalities carry promise. Funding patient participation in clinical trials is a major step in this direction. It is also important to ensure that new medical knowledge is developed in a manner that is fair to all patients, so that some groups (women, for example) are not left out. Funding participation in clinical trials is like-

189. Id. at 652.

190. Zervos v. Verizon, N.Y., Inc., 277 F.3d 635 (2d Cir. 2002).

191. Reed v. Wal-Mart Stores, Inc., 197 F. Supp. $2 d 883$ (E.D. Mich. 2002).

192. Am. Inv. Life Ins. Co. v. Butler, 65 S.W.3d 472, 474 (Ark. Ct. App. 2002).

193. Goepel v. Mail Handlers Benefit Plan, No. 93-3711, 1993 U.S. Dist. LEXIS 13346

(D.N.J. Sept. 23, 1993).

194. Jaecks v. Nat'1 Ass'n of Letter Carriers Health Benefit Plan, No. 93C6855, 1993 U.S.

Dist. LEXIS 16876 (N.D. Ill. Nov. 30, 1993). 
wise important to this end. If it is beneficial for patients to participate in clinical trials, justice requires that access to the trials is fair. None of these reasons, however, support encouraging patients to believe they are entitled to experimental care as though it were already established therapy. Unfortunately, this is what the courts seem to have done in ruling in favor of patients seeking high dose chemotherapy for breast cancer. This is also what statutes mandating coverage for off-label drug use and participation in clinical trials may do if the mandates are not carefully limited. In the case of off-label drug use, mandates should be limited to uses that have been scientifically validated; some, but not all, of the statutory mandates incorporate this limit. In the case of participation in clinical trials, coverage should be limited to trials that are likely to yield scientifically helpful results. Otherwise, the result may be further resort to courts by patients who have come to expect care as beneficial and believe, therefore, that the care is an entitlement. Even if these expectations have been encouraged by the law, however, they are not legitimate and thus are not grounds for moral entitlement, because the beliefs on which they are grounded are not reasonable. 
